\title{
Archaeological
} Prospection

\section{Archaeological applications of low-cost integrated sidescan sonar/single-beam echosounder systems in Irish inland waterways}

\begin{tabular}{|r|l|}
\hline Journal: & Archaeological Prospection \\
\hline Manuscript ID & ARP-15-0023.R1 \\
\hline Wiley - Manuscript type: & Research Article \\
\hline Date Submitted by the Author: & n/a \\
\hline Complete List of Authors: & $\begin{array}{l}\text { Westley, Kieran; University of Southampton, Coastal and Offshore } \\
\text { Archaeological Research Services } \\
\text { McNeary, Rory; Department of Agriculture, Environment and Rural Affairs, } \\
\text { Northern Ireland }\end{array}$ \\
\hline Keywords: & $\begin{array}{l}\text { sidescan sonar, marine geophysics, shipwreck, underwater archaeology, } \\
\text { crannog, logboat }\end{array}$ \\
\hline
\end{tabular}

SCHOLARONE ${ }^{m}$

Manuscripts 


\title{
Archaeological applications of low-cost integrated sidescan sonar/single-beam echosounder systems in Irish inland waterways
}

\author{
Kieran Westley ${ }^{1, *}$ and Rory McNeary ${ }^{2}$ \\ ${ }^{1}$ Coastal and Offshore Archaeological Research Services, University of Southampton \\ ${ }^{2}$ Marine and Fisheries Division, Department of Agriculture, Environment and Rural Affairs, \\ Northern Ireland \\ *Corresponding Author (K.L.Westley@soton.ac.uk)
}

\begin{abstract}
Inland waterways, such as rivers and lakes have been foci of human settlement and use for millennia. However, underwater archaeological prospection or survey in these environments is often hindered by poor or no-visibility conditions. While this can be overcome using a range of well-established geophysical techniques, their application in inland waterways seems comparatively less common than in offshore environments. Possible reasons include the logistical challenges of surveying shallow confined, often inaccessible and uncharted waters coupled with a wider lack of awareness of the submerged archaeological potential of inland waterways. This paper demonstrates one method by which the logistical challenge can be circumvented, specifically the use of low-cost acoustic systems which combine a single-beam echo sounder and sidescan sonar. These systems have appeared within the last decade and are smaller and cheaper than their survey-grade counterparts. Although developed for the sport fishing community, as shown here, they can also be used for archaeological purposes. Their effectiveness for archaeological prospection is illustrated via three case studies from lacustrine and riverine settings in Northern Ireland and by reference to object detection and bathymetric mapping. The data presented indicate that the low-cost systems are capable of collecting data that is sufficient for archaeological purposes but they are best suited to shallow confined waters where their disadvantages (limited range and depth of operation, reduced image quality) are minimized.
\end{abstract}

\section{Keywords}

Sidescan sonar, marine geophysics, shipwreck, crannog, logboat, underwater archaeology 


\section{Introduction}

Inland waterways such as rivers and lakes have been the focus of human settlement and exploitation for millennia. They provide fresh water, a range of subsistence resources, can form natural transport corridors or defensive barriers and may also constitute sites of ritual deposition. As a result, they comprise a rich multi-period archaeological and palaeo-environmental resource, often with organic remains wellpreserved by waterlogging (Coles, 1984; Coles and Coles, 1989; Coles and Lawson, 1987; Brown, 1997; Menotti, 2012; Menotti and O'Sullivan, 2013).

A large proportion of archaeological work has traditionally tended to focus either on sites currently above-water on the margins of these waterbodies or now-drained areas where the archaeology no longer lies in, or adjacent to, the former waterbody (e.g. Hencken, 1950; Collins, 1955; Bradley, 1991; Keane, 1995; Croes et al., 2009; Fredengren et al., 2010; Conneller et al., 2012; Palomo et al., 2014; Malim et al., 2015). Based on the published literature, comparatively less appears to have been accomplished on archaeological material which is presently submerged in inland waterways.

This relates at least partly to the challenge of undertaking archaeology underwater, particularly in inland waterways, which are often typified by low- to no-visibility conditions that make diver-based prospection, survey and excavation difficult, though not impossible (e.g. Farrell and Buckley, 1984; Kelly, 1993; Cantelas and Rodgers, 1994; Moore, 1996; Henderson, 1998; Tóth, 2009; Brady, 2014a; b). One means of overcoming this challenge is through use of geophysical techniques to either survey archaeological features or identify potential archaeological features (anomalies) that require follow-up targeted diver ground-truthing. The present range of such techniques includes sidescan sonar (SSS), sub-bottom profiler (SBP), single-beam echosounder (SBES), magnetometer and swath bathymetry (Quinn, 2011; Plets, 2013). These are all well-established techniques which are tried and tested in both commercial (Firth, 2011; Firth et al., 2012) and research projects (Quinn et al., 2002; 2005; Quinn, 2007; Bates et al., 2011). They have been variously used to locate and image shipwrecks (Papatheodorou et al., 2005; Quinn, 2007; Hamel, 2011; Plets et al., 2011), submerged structures (Sonnenburg and Boyce, 2008; Cassen et al., 2011) and map exposed or buried landscapes (Gaffney et al., 2007; Lübke et al., 2011; Bates et al., 2013; Westley et al., 2014). Nevertheless, even though the aforementioned techniques are all suitable for archaeological prospection in both freshwater and saltwater, based on the published literature, their deployment seems more common in the marine environment with relatively fewer examples from inland waterways (e.g. Duck and McManus, 1987; Stickel and Garrison, 1988; Rönnby, 1990; Henderson, 1998; Lafferty et al., 2006; Sonnenburg and Boyce, 2008; Plets et al., 2009; Tóth, 2006; 2009).

Several factors are probably responsible, one of which is certainly logistical (Plets, 2013). Many inland waterbodies are small, confined and uncharted. Thus, while the 
standard deployment consisting of a towed instrument, as is usual for SSS, magnetometer and SBP, works well on the open sea and larger lakes and rivers, it restricts the survey vessel's manoeuvrability and risks snagging the towfish in smaller shallow waterbodies (Parker et al., 2010). This can be overcome by pole-mounting the instrument over the bow or side of the survey vessel, but may entail extra equipment or cost. Also, placement of the instrument closer to the survey vessel's engines can increase the amount of noise in the data, since in very shallow water, enginegenerated bubbles in the water column take longer to dissipate resulting in acoustic blanking (Plets, 2013). In exceptional circumstances, such as detailed survey of a very small shallow area, this could necessitate a non-motorized deployment (e.g. Plets et al., 2009). For equipment which is usually hull-mounted, such as swath systems, standard equipment may be too large or complex for the small boats needed in confined waterways, unless dedicated shallow water/small boat setups are used (e.g. Bates et al., 2013; Bates and Fenning, 2013; see Hare, 2008 for review of considerations in small boat surveys). A further, and perhaps more fundamental reason, is a wider lack of awareness of the potential of the submerged component of inland waterways (Firth, 2014). This creates a vicious circle in that without awareness, there is less impetus to commission or conduct underwater geophysical survey, and without successful examples of said work, awareness is hard to raise.

As a result, inland waterways may hold a significant archaeological resource which, as yet, is often poorly recorded and quantified. Moreover, this record is under threat from urbanization, dredging (for navigation and aggregates), water abstraction, canalization/river realignment, hydro-power schemes and flood management (McNeary, 2011; Firth, 2014). Some of these activities, such as flood management, may well increase in the near future given the impact of climate change (Howard et al., 2008; Howard et al. in press). Therefore, there is a clear need to quantify and document the submerged resource and, in so doing, facilitate more proactive research and management.

To support this, there is a need to raise awareness of this archaeological potential and provide examples of work which have been able to deal with the logistical and/or technical challenges described above. With this in mind, this paper will report on archaeological survey in a range of confined inland waterways based around the use of a low-cost integrated SSS and SBES system. The primary motivation is to provide case studies of method and interpretation which can supplement the extant but relatively sparse body of published material and give stakeholders an example of a rapid and cost-effective means of how the challenge of working in these environments can be overcome.

\section{Background: Archaeology of inland waterways in Ireland}

The case studies presented in this paper are drawn from the island of Ireland which itself provides an excellent example of the archaeological potential of inland waterways, both large and small (O'Sullivan, 1998; O'Sullivan, 2007). Ireland has a 
profusion of rivers and lakes ranging in size from small streams and ponds to Lough Neagh (the largest freshwater body in the British Isles at $392 \mathrm{~km}^{2}$ ) and the River Shannon (c. $360 \mathrm{~km}$ long and $>2 \mathrm{~km}$ across at its widest). Such environments have been used since the island's first settlement with concentrations of Mesolithic sites along, for example, the River Bann (Woodman, 2015), and also situated on lakeshores at sites such as Lough Boora (Ryan, 1980) and Lough Kinale (Fredengren et al., 2010). Though the succeeding Neolithic period appears to have less direct evidence for use of inland waterways, in the Bronze Age there is a renewed intensification in settlement and use of these environments. This includes settlement sites on lake shores and islands, and the construction of artificial islands, known as crannogs (O'Sullivan, 1998; 2007).

Crannogs in particular represent one of the most pervasive indications of human use of inland waterways in Ireland, with up to 2000 known examples found across the island and concentrating mainly in a band stretching across southern Ulster and the adjacent counties of north and central Connacht (Fredengren, 2002; Neill, 2014). They also continue to be built and used after the Bronze Age and through both Early and Late Medieval Periods (i.e. up to $17^{\text {th }}$ Century AD) though their most intensive phase of construction appears to have been between the $6^{\text {th }}$ to $10^{\text {th }}$ Centuries AD (Fredengren, 2002; O'Sullivan and Downey, 2005; O'Sullivan, 2007).

Activity along inland waterways is also reflected in the presence of considerable artefact assemblages, with hundreds of small finds that have been dredged from Ireland's rivers. For instance, lithic, bone and metalwork assemblages have come from the Bann (Bourke, 2001; McNeary, 2011; Woodman, 2015), Blackwater (Bourke, 1998; Bourke, 2001) and Shannon rivers (Raftery, 1982; Condit and O'Sullivan, 1999; Bourke, 2001). Much of the material is prehistoric, ranging from the Mesolithic to the Iron Age, but there are also examples of Medieval metalwork (e.g. Bourke, 1998). Some material may have accumulated as a result of accidental loss, but the quantity, type and distribution of material also suggest votive deposition for ritual purposes (Bourke, 2001; O'Sullivan, 2007).

Travel across and along inland waterways is also demonstrated by at least 450 , and potentially up to 560 logboat discoveries ranging in date from the Mesolithic to as late as the $18^{\text {th }}$ Century $A D$, of which the vast majority are from riverine or lacustrine contexts (Fry, 2000; K. Brady, pers. comm. 2016). This has been recently highlighted by the discovery of at least 14 well-preserved logboats, dating from c. $2500 \mathrm{BC}$ to the $12^{\text {th }}$ Century AD in Lough Corrib (Brady, 2014a; Brady, 2014b). From the late $18^{\text {th }}$ to early $19^{\text {th }}$ Century onwards, inland navigation along rivers and newly constructed canals also formed a major part of Ireland's burgeoning transport infrastructure (McCutcheon, 1980; Delany, 1988).

Despite the considerable quantity of archaeological evidence from Irish inland waterways, and an obvious recognition of their archaeological potential (Boland, 1994; O'Sullivan, 1998; O'Sullivan, 2007; McNeary 2011), the pattern of investigation largely follows that discussed above. Most archaeological evidence has come from peatland, bogs (i.e. former wetlands), lakeshores, islands or dredged assemblages. There are 
some notable exceptions with diver-led work being undertaken by the Crannog Archaeological Project (CAP) between 1983 and 1993 in midland lakes (Farrell and Buckley, 1984; Farrell, 1989; Farrell et al., 1989) and by the Underwater Archaeological Research Team (IUART) in the 1990s on river fords and loughs (Boland, 1994; O'Connor, 1989; Lavelle, 1992; Kelly, 1993). A prominent find during the period of research in the 1990s was the Early Medieval wooden bridge across the River Shannon at Clonmacnoise (Moore, 1996; Boland and O'Sullivan, 1997). More recent years have seen a multi-disciplinary project (including archaeological diving) focused on Coolure Demesne crannog in Lough Derraveragh (O'Sullivan et al., 2007) and also discoveries made through development-led underwater work such as Medieval and Post-Medieval bridge remains located during the River Nore flood alleviation scheme at Kilkenny (Brady, 2000; 2001). However, with the exception of Lafferty et al. (2006), McNeary et al. (2013) and Brady (2014a; 2014b), there are very few published examples of underwater remote sensing survey work on the submerged portions of the archaeological record.

While it might be expected that only larger water bodies would likely be foci of settlement and activity, it should be noted that structures such as crannogs can be found in lakes $<200 \mathrm{~m}$ across. Indeed, the overall crannog distribution pattern suggests a preference for small lakes, with relatively few found in large waterbodies such as Loughs Erne, Ree, Derg and Neagh (O'Sullivan and Downey, 2005). Many dredged finds and logboats also come from channels a few tens of metres across. Thus, smaller, more confined waterways which are difficult to survey should not be automatically written off as candidates for remote sensing investigation. Three such waterways located in Northern Ireland are discussed in this paper as representative case studies (Figure 1).

\section{Methodology}

The survey method demonstrated here comprises sidescan sonar (SSS) and singlebeam echosounder (SBES). However, it does not use a conventional towed SSS instrument combined with a separate SBES transceiver. Rather it uses a low-cost system which integrates both instruments into a single package. These low-cost systems have appeared within the last decade aimed principally at the sport fishing community (McNeary et al., 2013; Kaeser et al., 2013). There are three immediately noticeable differences with traditional systems. Firstly, the low-cost/sport fishing systems are much smaller, with transceivers measuring c. $20 \mathrm{~cm}$ long that are designed to be mounted on the hull or an outboard engine. Secondly, they integrate an SBES alongside the SSS allowing bathymetry to be derived as an additional product from the same unit. Finally, they are much cheaper, retailing in the hundreds of pounds range versus the tens of thousands of pounds typical of survey-grade systems.

Their small size, portability and integration of both SSS and SBES into a single unit makes them immediately attractive for work in confined waterways where small shallow draft boats are essential. The chief disadvantage is that these systems are not 
capable of the same level of precision or image quality as survey-grade SBES or SSS systems. There are also a number of operational limitations which will be discussed further following the case studies. Nevertheless, as we demonstrate here, they can still be effective for archaeological purposes in certain environments, namely confined inland waterways.

The low-cost system used in the following case studies is a Lowrance Structurescan ${ }^{\circledR}$ LSS-1 HDS (hereafter referred as the LSS-1). This comprises both SSS and SBES, a processing unit and a display/control unit incorporating a WAAS/EGNOS-enabled dGPS. The SSS component offers two operating frequencies: low resolution/high range $(455 \mathrm{kHz})$ and high resolution/low range $(800 \mathrm{kHz})$. The integrated SBES (referred to by the manufacturers as the Downscan ${ }^{\circledR}$ ) images high-resolution profiles from directly beneath the transceiver thus filling in the gap between port and starboard SSS channels. An additional conventional SBES transceiver can also be directly connected to the display/control unit and run simultaneously alongside the SSS and Downscan ${ }^{\circledR}$ transceivers.

The LSS-1 was acquired in 2011 by the Centre for Maritime Archaeology, Ulster University as part of a remit to investigate inland waterways (McNeary and Bourke, 2009; McNeary, 2011; McNeary et al., 2013). From the outset, it was intended to be transferable between small shallow draft vessels of opportunity. Therefore the topside unit (incorporating battery, processing and display/control units) was installed within a portable waterproof case and a variety of mounting plates and arms were constructed to hold the transceiver heads (Figure 2A). All equipment was improvised in-house at low cost, often from second-hand materials.

The survey platform used most frequently in inland waterways is a $3.5 \mathrm{~m}$ plastic-hulled boat powered by a $20 \mathrm{hp}$ petrol outboard or $12 \mathrm{~V}$ electric engine (Figure $2 \mathrm{~B}$ ). The transceiver heads are hull-mounted on a removable plate located on the transom and offset to starboard (Figure 2C). This craft is sufficiently small and has a shallow enough draft to cover the majority of confined waterways, but is also stable enough to survey larger bodies of water. On occasions, the LSS- 1 has been used on either a $6.5 \mathrm{~m}$ Rigid Hull Inflatable Boat (RHIB) powered by twin $90 \mathrm{hp}$ petrol engines or a $2 \mathrm{~m}$ inflatable powered by a $12 \mathrm{~V}$ electric engine. These respectively cover larger rivers and lakes and small inaccessible waterways. The latter craft is particular well-suited for locations with no boat or trailer access (Figure 2D). In both cases, the transceiver heads are mounted on a detachable rigid arm rather than the hull.

Although the system has been used on different vessels and in different waterbodies, it has not been standard practice to bar test it or correct for variations in sound velocity. This is because, as stated previously, the low-cost system is not capable of achieving the precision required of survey-grade equipment. Given that sound velocity errors propagate with increasing distance from the transducer, in the shallow waters $(<10 \mathrm{~m})$ where the LSS-1 is most commonly used the errors are relatively small (c. $15 \mathrm{~cm}$ max for a difference of $5^{\circ} \mathrm{C}$ or $15 \mathrm{psu}$ at c. $10 \mathrm{~m}$ depth/two-way-travel-time of $0.015 \mathrm{~ms}$ ). 
We feel that this margin of error is acceptable given that the aim of the bathymetric surveys conducted to date has been to provide a rapid general characterization of depth to guide survey planning in uncharted waters, rather than to obtain hydrographic-quality data, where precise absolute depth measurements are necessary for safety of navigation. That said, on occasion (see below), this data has also later proved to be of use in archaeological interpretation.

Post-survey, the acquired data are imported as s/2 files (proprietary Lowrance format containing both SSS and SBES data in a single file) into Reefmaster software for processing and visualization. SBES data are first checked for spurious datapoints which are manually removed or adjusted. Tidal and/or vertical datum corrections can also be added at this stage if necessary. Individual SBES lines are then combined and gridded into a raster bathymetric surface using Reefmaster's in-built processing. These rasters can then be exported for use in Geographical Information Systems (GIS) software. Playback of SSS data and identification of archaeological anomalies is also done in Reefmaster with anomalies tagged as waypoint sets which can later be imported into GIS software. However, creation of georeferenced raster mosaics of SSS imagery is usually done using SonarTRX software as this allows greater user control compared to Reefmaster which is largely automated. The standard processing workflow for SonarTRX comprises: 1 ) Speed correction using readings from the LSS-1's in-built GPS; 2) Slant range correction to remove the water column; 3) Beam Angle Correction to balance backscatter intensity across track; 4) Application of Time Varying Gain and/or global gain and contrast as required; 5) Mosaic to georeferenced raster format for import to GIS.

Since its acquisition, the LSS- 1 has been deployed in a number of inland waterways in the Republic of Ireland and Northern Ireland (see McNeary, 2012a; McNeary, 2012b; McNeary et al., 2013). Three such examples covering both riverine and lacustrine settings are presented here, while data from a fourth is used in the discussion to highlight particular aspects of the system's capabilities (Figure 1).

\section{Case study 1: Riverine Environment, Dunnalong}

\section{Site description}

Survey was conducted on the River Foyle, a $129 \mathrm{~km}$ long waterway which drains the northwest of Ireland. The specific focus of survey was the site of Dunnalong, a starshaped artillery fort and associated settlement located c. $17 \mathrm{~km}$ upstream from the river mouth. This was done as part of a wider community archaeology project centred on Dunnalong fort, which had been built by the English in 1600 on the site of an earlier $\left(16^{\text {th }}\right.$ Century AD) Gaelic tower house during the 'Nine Years War' between the English and the Irish (Roulston, 2013). This was a strategic location controlling an important river crossing and salmon fishery, as well as providing a port for shipping along the Foyle River. 
The overarching project spanned both land and water. The inland portion of the site was subject to geophysical survey (resistivity and magnetometry) to define the extent of the fortification and identify structural remains within it (McHugh, 2013) while targeted excavation was conducted over sections of the former defences and potential structural remains (Logue and McHugh, 2013). The riverine component of the project was more exploratory as no previous field study had been made of either the foreshore or the riverbed despite the site's role as a fishery, ferrying point and port. The only recorded historic assets in this regard were the location of four fishing 'shots' in the general vicinity, a causeway and associated ferry and two logboats hauled up by fishermen in the early $20^{\text {th }}$ Century (Wallace, 1917).

\section{Survey aim and method}

No nautical charts exist for this section of the Foyle River. Consequently, at the time of survey, the only information available was that the channel was wide (c. $600-900 \mathrm{~m}$ across), tidally influenced with shoals exposed at low water, and with strong currents (c. $4.5 \mathrm{kts}$ average but increasing depending on the wind and tide). Therefore, the aim of the survey was twofold (McNeary, 2012a; McNeary, 2013):

1) To obtain bathymetric data which could guide any future survey; and,

2) To identify if any archaeological material relating to Dunnalong was present on the riverbed.

An area of c. $1.5 \mathrm{~km}^{2}$ covering the entire width of the channel in the vicinity of the former settlement was accordingly surveyed over two phases. Phase 1 was a reconnaissance survey which aimed to rapidly characterise the local bathymetry and general riverbed conditions. The objective of Phase 2 was then to focus on a more limited area where it was felt (on the basis of Phase 1 ) that there was the most archaeological potential. Parameters for each Phase are summarized in Table 1 . In both cases, the $3.5 \mathrm{~m}$ shallow-draft boat with transom-mounted transducers was used.

Although the site is tidal, no vertical corrections were applied to the acquired bathymetric data because site-specific tide records were not available. We regard the resulting degree of vertical error as acceptable given the aim of the bathymetric component of the survey (rapid characterization of depth), the accuracy of the system as mentioned previously and the actual amount of tidal fluctuation during each Phase (c. $0.2-0.3 \mathrm{~m}$ based on tidal data from Lisahalley, the only tide record on the Foyle, c. $17 \mathrm{~km}$ downstream). However, bathymetric data from each Phase have not been combined as the absolute difference in tide level between each is not known and only bathymetric data from Phase 1 are used in the images and interpretation presented here. All depths are therefore relative to the water level at time of survey.

Results 
Bathymetric data collected during Phase 1 show that channel in the vicinity of Dunnalong ranges in depth from $0-8 \mathrm{~m}$. The deepest section is located c. $60-100 \mathrm{~m}$ off the northern shore and forms a c. $300 \mathrm{~m}$ long by $90 \mathrm{~m}$ wide depression. By contrast, water depths on the opposing shore immediately adjacent to Dunnalong are generally shallow $(<1-2 m)$. This shallow area is separated from the main channel by a sand bar $c$. $400 \mathrm{~m}$ long by $80 \mathrm{~m}$ wide which is visible at low water and was a recognized salmon net hauling ground used within living memory and artificially raised to form a cairn from which nets could be deployed on a rising tide. A deeper pool up to c. $3.5 \mathrm{~m}$ deep and c. $130 \mathrm{~m}$ by $60 \mathrm{~m}$ across lies directly off the fort and is sheltered from the main channel by another sand bar, also clearly visible on the bathymetric data (Figure 3).

Inspection of the data following Phase 1 resulted in Phase 2 focusing specifically on the deeper pool lying immediately off the fort. This decision was made firstly because the proximity of the pool to the southern causeway suggested it could have served as a loading/unloading area (see interpretation below). Secondly, the distribution of SSS anomalies also suggested a potential concentration in/around the southern pool (Figure 3). Inspection of the SSS data from both Phases indicated a total of 50 anomalies, comprising either individual small $(<2 \mathrm{~m})$ upstanding objects, or clusters of features. The individual anomalies are spread across the study area, whereas the clusters concentrate at the southern pool and its immediate environs (Figure 3 ). In general, the clusters consist of upstanding features ranging in size from 1 to $4 \mathrm{~m}$ across and include both regular (e.g. linear) as well as irregular shapes (Figure 4).

Interpretation

Although the original intention of the bathymetric survey was to obtain sufficient data to guide future survey, the acquired data actually proved to have some use for archaeological interpretation. Overlaying the bathymetric data with historic maps indicated that the two deeper pools are situated at the terminus of stone ferry 'causeways' on both sides of the river. The causeways are marked on mid- to late $19^{\text {th }}$ Century Ordnance Survey Second Edition map (Figure 3) and sections of them remain visible on the foreshore at low water (McNeary, 2012a; McNeary, 2013). Their submerged tips are also recorded on individual SBES profiles as distinct peaks upstanding from the river bed by $0.5-0.6 \mathrm{~m}$ (Figure 3 ). Though the causeways are undated, documentary sources mention the presence of quays and a ferry at Dunnalong from as early as 1622 (Roulston, 2010). This finding seems to reflect a clear rationale when it came to the original siting of the settlement. In addition to the river being relatively narrow at this point, the deeper pools would have facilitated the loading and unloading of persons and goods at all states of the tide. They may also have served as an anchoring point at high water for larger draught vessels, such as the vessels of up to 200 tons recorded by documentary sources as reaching Dunnalong (Hunter, 2011) and one- and two-masted sailing vessels depicted on $17^{\text {th }}$ Century maps anchored off Dunnalong (Roulston, 2013).

The majority of the anomalies detected by the SSS survey are small $(<2 \mathrm{~m})$ objects 
slightly upstanding from the riverbed which cannot be verified as archaeological features on the basis of the SSS imagery alone. It is likely that many are natural features, for example partly buried boulders or tree trunks such as can be seen on the immediate muddy foreshore at low water off Dunnalong (McNeary, 2012a). An exception is the submerged tip of the southern causeway which appears on the SSS as a linear NNE-SSW aligned feature terminating in a cluster of small rounded anomalies (Figure 4). This fits with the intertidal potion of the causeway visible at low water which comprises a line of boulders c. 2-3m wide with vertical wooden stakes occasionally visible along its edges (Figure 5; McNeary, 2012a). Another area of archaeological potential is the dense cluster of upstanding anomalies, including linear features up to several metres in length within the southern pool (Figure 4). These have the general appearance of debris, though this has not been verified by diver inspection. However, historic sources describe repairs to the quay at Dunnalong in 1768 as follows: "The quay will require to be ten perches in length and nine foot broad, that by taking down three feet of each side of the old quay, that by rebuilding it and properly joining it to three feet of the old work in the centre may answer when fully bound with timber along each side, large bars across and staked to secure stones from falling...the timber must be well bound with wood pins as iron would very soon rust and break with the salt water, but there must be some staples and rings to make the boat fast." (John Sinclair to Earl of Abercorn 1768, PRONI Public Record D623/A/37/120; cited in Roulston, 2013: 14).

This implies a substantial quantity of wood and stone was used in both the original and re-built quays; therefore it would not be unreasonable to surmise that much of this material later accumulated in the adjacent pool as the structure deteriorated when it fell out of use. Although it is possible that some of the material could be natural flotsam (e.g. trees and branches) which has become trapped in this pool, the very dense concentration does contrast strongly with the otherwise scattered nature of the anomalies across the surveyed area (Figures 3 and 4).

\section{Case study 2: Lacustrine Environment, Coney Island}

\section{Site description}

Survey was conducted around Coney Island, a small island in the southwest corner of Lough Neagh, the largest freshwater body in the British Isles at c. $382 \mathrm{~km}^{2}$ (UK Lakes Portal, 2016) (Figures 2 and 6). The size and depth (8.9m average) of the lake meant that large areas had been previously surveyed with a conventional SSS and SBES deployment. However, inshore areas such as around Coney Island were not surveyed as they are shallow, restricted and thus difficult to work in using a conventional setup (McKenna et al. 2008).

The Coney Island locale was chosen for survey because of a high archaeological potential linked to its long history of occupation and use. The island had been variously occupied during the Mesolithic, Neolithic, Bronze Age and Medieval periods and, in the 
$13^{\text {th }}$ Century AD, became an Anglo-Norman frontier post sited to control access to two nearby rivers (the Bann and Blackwater: Figure 6) which drain into the Lough. It later became a stronghold of the O'Neill clan in the $16^{\text {th }}$ Century AD and was '...thought to be the most strength of any that he [Shane O'Neill] had, and where he kept his plate, jewels and apparel' (Cal. State Papers, Carew MSS., 1575-1588, 339, cited in Addyman 1965:80). It was handed over to Sir Henry Sydney in 1567 and put under the command of James Vaughan and continued in use as a military stronghold into the early $17^{\text {th }}$ Century. In the late $19^{\text {th }}$ Century the island became the retreat of Lord Charlemont, who built a modern cottage on the island (Addyman, 1965). Tradition also records that St. Patrick, the patron saint of Ireland, visited Coney Island during the $5^{\text {th }}$ Century AD via a causeway which extended from the mainland out to the island. Given the religious significance of this visit, this then later formed part of a pilgrimage route leading to Armagh City. This causeway, known as St. Patrick's Road, was said to have been partly removed during the early 19th century to allow for the passage of barges from the Bann to the Blackwater River via the Maghery Canal (Addyman 1965).

Despite this history, the underwater environs of Coney Island had never been subject to previous archaeological survey. Recent concerns had also been raised by the Lough Neagh Partnership (a local non-profit organization engaged in managing, conserving and enhancing the Lough environment whilst developing economic and social opportunities) regarding future programmes of dredging in the locality for navigation purposes. It was therefore felt timely to conduct an underwater survey of the surrounding lakebed.

\section{Survey aim and method}

Unlike Dunnalong, limited hydrographic data was available in the form of Admiralty Chart 2163 (published 1983; 1:40,000 scale). Although most charted depths in the Lough were based on a 1981 SBES survey, close inshore areas were not surveyed and thus, depths to the south of Coney Island are still based on an 1835 lead line survey (McKenna et al., 2008). Nonetheless, though sparse, these indicated significant areas of shallows around the island (c. $<-2 m$ Chart Datum) which would make a conventional towed SSS deployment difficult.

The sonar survey therefore had three primary aims:

1) To obtain up-to-date bathymetric data to guide any future survey;

2) To identify if any archaeological material was present on the riverbed with particular focus on the possible remains of St. Patrick's Road; and,

3) To ground-truth potential archaeological remains by diving.

An area of c. $0.4 \mathrm{~km}^{2}$ covering the inshore area between Coney Island and the mainland along with a single circuit around the island was accordingly surveyed in two Phases. 
Phase 1 was a reconnaissance survey which aimed to rapidly characterise the local bathymetry and general lakebed conditions and as well as identifying potential archaeological features. Phase 2 was then was subsequently carried out to obtain further imagery over anomalies of high archaeological potential identified from Phase 1. This in turn was followed by a third phase comprising diver inspection of the aforementioned high potential anomalies. Parameters for each acoustic survey are summarized in Table 1 . In both cases, the $3.5 \mathrm{~m}$ shallow-draft boat with transommounted transducers was used. Tidal corrections were not necessary at this site as the lake is not tidal. Therefore, all depths are relative to lake level at the time of survey.

\section{Results}

SBES data indicated the presence of a natural shoal or ridge ranging in depth from 0.4$1.2 \mathrm{~m}$ at the southwest tip of Coney Island. To the south, this gives way to a deeper (up to c. $2.5 \mathrm{~m})$ depression and to the west is separated from shallows $(<1.75 \mathrm{~m})$ by a deeper channel (Figure 7). As for Dunnalong, while the original intent of the bathymetry data had been to guide future survey, it also provided information for archaeological interpretation (see below).

The SSS survey detected a total of 25 anomalies comprising mainly of small ( $<3 \mathrm{~m}$ long) features upstanding from the soft lakebed. This included a number of linear features, which could represent archaeological assets such as upturned or partly buried logboats or alternatively could be large branches or tree trunks embedded in the lakebed mud (Figure $8 \mathrm{C}$ ). A series of narrow sub-parallel grooves up to $50 \mathrm{~m}$ long located c. $175 \mathrm{~m}$ southwest of the island probably represent anchor drag marks or possibly scars related to former dredging activity (Figure 8D).

However, two anomalies stood out as having high archaeological potential and were accordingly re-surveyed in Phase 2 . The first was located c. $250 \mathrm{~m}$ south of Coney Island in a water depth of $2.5 \mathrm{~m}$. It appeared on the SSS to be an upstanding oval-shaped anomaly $10.7 \mathrm{~m}$ in length and up to $4.6 \mathrm{~m}$ wide with clearly raised sides and a rounded or tapering end (Figure $8 \mathrm{~A}$ ). Two further upstanding linear features were visible cutting across the anomaly and additional square upstanding features located immediately to its south. Overall, it had the appearance of a sunken boat with associated debris and/or displaced cargo. The second anomaly was located close to the southeast shore of the island in a water depth of $1.6 \mathrm{~m}$. It appeared on the sonograph to be a $7.5 \mathrm{~m}$ long by $1 \mathrm{~m}$ wide linear feature with two upstanding sides, reminiscent of a logboat (Figure 8B).

Due to their high potential nature, these two anomalies were subject to diver inspection which confirmed the initial interpretation. Despite the poor visibility $(<0.3$ $\mathrm{m})$, the first anomaly was confirmed as a timber boat with iron fittings. The diver verification also revealed that it was carrying a cargo of roof and ridge tiles which appear to be $19^{\text {th }}$ Century or later in date. The second anomaly was confirmed as a substantial logboat with upstanding gunwales and evidence for internal fittings. 
Moreover, the small anomaly visible at its northern end was confirmed as a second partial logboat partly buried under it (Figure 8B).

\section{Interpretation}

The shoal is likely the remnant of the causeway and, given its depth, would have been fordable, particularly at times of low lake level. This is supported by the depiction of the causeway on the Ordnance Survey $2^{\text {nd }}$ Edition historic maps and associated memoir (Day and McWilliams, 1990) (Figure 6). These sources suggest that the causeway ran south-southwest to the mainland. However, this route (Figure 7: A-A') cuts across a $250 \mathrm{~m}$ wide channel up to $2.4 \mathrm{~m}$ deep, much wider than might be expected for a dredged passage. Therefore, alternative routes, based on the bathymetry, run to the west (Figure 7: C-C') and southwest (Figure 7: B-B') of the island (Figure 6). In both cases, these routes cross depths of $\mathrm{c} .1 .7 \mathrm{~m}$ to $1.5 \mathrm{~m}$ and are cut by clear 30-60m wide channels up to $2 \mathrm{~m}$ deep which are more representative of dredged passages. If the western alternative (Figure 7: $C-C^{\prime}$ ) was a viable route then the siting of the castle (O'Connor's Stronghold: Figure 7), would allow it to control access to the causeway as well as guard the mouth of the nearby Blackwater River. However, the location of the southwestern route (Figure 7: B-B') fits better with the aim of the dredging, which was to create a direct passage from the Bann to the Maghery Canal and therefore, may be the most likely candidate for the former causeway. No structural remains suggestive of the causeway outside the dredged/deeper areas were imaged by the SSS data, suggesting one of two possibilities. Firstly, any remains have since been buried by lakebed sediment, or secondly, that the causeway was a natural shallow without any anthropogenic modification.

At present, little more can be said of the boat finds other than the larger wooden boat based on the SSS result and diver verification is likely a shallow draft barge or lighter. Such vessels would have navigated former canal systems in Ulster and, the location of the boat suggests that it plied either the Ulster Canal (opened 1842) and/or the Tyrone Navigation (opened 1787) both of which were reached via the Blackwater River.

However, its width of 4-4.6m (based on the SSS imagery) favours the latter given that the Ulster Canal was built narrower than other Irish canals, with majority of locks 12 foot (3.7m) wide (McCutcheon, 1980; Delany, 1988). This is also supported by the vessel's cargo of roof tiles. The Tyrone Navigation formed the main conveyancing route for coal from Coalisland coal works as well as sand, tiles, bricks, pottery and fireclay goods (all of which were manufactured locally) via the Coalisland Canal and Blackwater River into Lough Neagh and thence to Belfast via the Lagan Navigation (opened 1794) or to Newry via the Upper Bann and Newry Navigation (opened 1732). From here, the cargo was then moved onward, principally to Dublin, by sea (McCutcheon, 1980). The mouth of the River Blackwater was prone to silting and the Maghery Canal section was excavated in c. 1800 to further facilitate barge traffic and eventually abandoned in 1931 (Delany, 1988). Given the shallows and shoals around Coney Island, a more likely route prior to construction of the Maghery Canal (and the associated dredging) would have been to the north of the Island, making use of deeper water. Therefore, the 
position of the wreck to the south of the Island makes it more like that it was in use and sank during the lifetime of the Maghery canal (c.1800-1931).

With the logboat finds, there is little in the way of chronological accuracy; no samples were taken for dating, so their precise age remains to be confirmed. As previously stated, logboats are not uncommon finds from Irish inland waterways, with as many as 560 recorded examples ranging in date from the Mesolithic to the Post-Medieval (K. Brady pers. comm. 2016). For Lough Neagh specifically, not including the finds described here, 30 logboats have been previously recorded ranging in age from the Mesolithic (Brookend logboat: 5490-5246 BC) to the Medieval (Derryloughan boat 2: 1430-1620 AD) (Fry, 2000). Eleven of these logboats cluster in the southwest corner of the Lough; two possibly from the Lough itself and others dredged from the Bann, Blackwater or excavated from bogs (Lanting and Brindley, 1996; Fry, 2000; McNeary, 2010). Given the long occupation history of Coney Island (Addyman, 1965) and the occurrence of similar boat finds in the locale, their presence at a river/lough confluence is not to be unexpected.

\section{Case study 3: Lacustrine Environment, Moorlough Lake}

Site description

Survey was conducted within Moorlough Lake, a small inter-drumlin lake located in County Fermanagh. The lake measures $950 \mathrm{~m}$ by $300 \mathrm{~m}$ across, representing an area of c. $0.22 \mathrm{~km}^{2}$. No information was available on the lake's depth or substrate because it had never been surveyed. Moorlough Lake is a typical example of the small lakes which are a common feature of the drumlin belt of north-central Ireland. Many of these contain known historic assets in the form of crannogs, and within Co. Fermanagh, there appears to be a preference for crannogs to be located within small, relatively isolated bodies of water (O'Sullivan, 1998; Neill, 2014). Despite this evidence of past usage, these lakes are usually uncharted but their archaeological potential has been reflected by the work of antiquarians in the late 1800s (Wakeman, 1870-1; Wakeman, 1872; Wood-Martin, 1886) and more recent archaeological study (Williams, 1993; Foley and Williams, 2006; Bermingham et al., 2013). But despite past work on Fermanagh crannogs, almost half (64) of the 142 recorded crannogs within the County have not been positively identified and are listed only as probable crannogs. In the case of Moorlough, a small circular island at its southern end is recorded in the Northern Ireland Sites and Monuments Record (NI SMR) as a 'probable' crannog. This assessment had been made on the basis that a small circular island was depicted on the Ordnance Survey $1^{\text {st }}$ Edition map (though not on the $2^{\text {nd }}$ Edition). At the time of survey, it had not been visited or subject to archaeological recording to verify this assertion (FER 246:062: NI SMR, 2016).

\section{Survey aim and methods}

Moorlough Lake was chosen for survey as part of a wider pilot project which aimed to 
verify whether fully submerged, and hence unrecorded crannog remains, were present within Co. Fermanagh's small inter-drumlin lakes (Henry et al., 2014). Survey concentrated primarily in the deeper portions of the lake where minor water level fluctuations might not be expected to reveal fully submerged crannogs and secondarily in the environs of the probable crannog at the southern end of the lake.

The primary aim of the survey was therefore to:

1) To identify if submerged crannog remains were present on the lakebed.

Secondary aims were:

2) To identify if any archaeological material was present on the lakebed; and,

3) To ground-truth potential archaeological remains by diving.

Parameters for the survey are summarized in Table 1. Tidal corrections were not necessary as the lake is not tidal. All depths are therefore referenced to the lake level on the day of survey

Results

Survey conducted over the lakebed found no evidence for any fully submerged crannogs on the lakebed. Instead, the SBES data showed a flat or gently sloping lakebed, with no anomalous mounds as might be expected if a crannog was present (Figure 9). The SSS data also showed no indication of upstanding sub-circular features or debris which might characterize a sunken crannog (e.g. Duck and McManus, 1987). In fact, the majority of the lakebed was largely featureless, with 17 small anomalies spread out across the lough with small clusters along the central part of the lake and its north-eastern margin (Figure 9). These comprise various small ( $<2-3 m$ across) upstanding features or depressions which appear different to the natural acoustic signature of the lake. The precise origins of the majority of the anomalies are unclear as they were not subject to ground-truthing, and many are likely natural features such as partly buried branches, tree trunks or boulders.

However, results from the environs of the small island were more encouraging. The SSS data clearly delineated the northern perimeter of the island, showing it to be a distinct circular mound with a diameter of c. total diameter of c. $35 \mathrm{~m}$ versus the above water diameter of $20 \mathrm{~m}$. The shallows around the southern, western and eastern edges the island however, were choked with aquatic vegetation, which was difficult to penetrate with either the SBES or SSS. The acquired data however, hint at the continuation of the submerged circular perimeter. In addition, two closely spaced vertical upstanding anomalies were imaged $35 \mathrm{~m}$ north of the island's shoreline and a series of small low-lying anomalies can be seen on the western side of the island slope (Figure 10). 
This information was verified by diving which confirmed a shallow slope running down from the edges of the island. This was more pronounced on the northern than the southern perimeter (2.7-2.5m versus $1.2-1.3 \mathrm{~m}$ depth at slope base). The slope was comprised of stone covered in silt and shell, with some reclining timbers visible. These timbers and occasional larger stones/boulders could represent the low-lying anomalies imaged on the island's slope. This contrasted with the natural lakebed at the base of the slope which consisted of soft and fluid fine sediment. The two vertical anomalies northwest of the island were identified as upright wooden posts extending above the lake bed with one post exceeding $1 \mathrm{~m}$ in height. Walkover survey above water further confirmed the artificial nature of the island. Erosion on the northern side had revealed a section of earth and stone, as well as four upright timber piles ranging in diameter from $0.1-0.3 \mathrm{~m}$. In addition at least three reclining timbers were observed in section as well as a number of larger stones $(0.5 \times 0.3 \mathrm{~m}$ max $)$.

\section{Interpretation}

The combined above and below-water work have confirmed that the island is indeed man-made and therefore a crannog, as defined by Fredengren (2002). This is based firstly on the evidence that the island is man-made, as indicated by the presence of structural timbers on the foreshore and the circular berm underwater which is similar to that of previously studied crannogs (e.g. Fredengren et al., 2010) including examples imaged by SSS (e.g. Duck and McManus, 1987). Secondly, there is no indication that water levels were lower when the structure was constructed and prevented it from being an island. This comprises a lack of evidence for submerged palaeoshorelines/breaks in slope visible on either the SSS or SBES data or evidence for changing water levels from historic maps, given that both $1^{\text {st }}$ and $2^{\text {nd }}$ Edition Ordnance Survey maps depict broadly the same shoreline position as modern aerial photos. The location of the Moorlough crannog also broadly fits with the general pattern identified by Fredengren (2002); namely a preference for gently sloping shorelines. The steepest shorelines lie along the entire western side of the Lough, whereas its southern and eastern sides are characterized by much more gentle gradients (Figure 9).

Based on Fredengren's (2002) classification system, this particular crannog can be described as a high, even-sectioned, circular crannog mound. Its diameter, based on the full extent of the submerged berm, is c. $36 \mathrm{~m}$ (NE-SW direction) by at least $35 \mathrm{~m}$ (NW-SE direction). This contrasts with the above water diameter of c. 20-22m and puts this crannog at the upper end of the size scale of these monuments. For instance, O'Sullivan and Downey (2005) consider 18-25m diameter to be 'relatively large' whilst Fredengren (2002) identifies average crannog diameter and height above lake bed as $25 \mathrm{~m}$ and $1.5 \mathrm{~m}$ respectively. In this case therefore, the SSS survey has demonstrated that the above water portion of the site does not provide an accurate guide to the full size of the former monument.

No definitive evidence was identified of an encircling wooden palisade by either diving 
or the SSS. It possible that the stumps of the palisade have since been buried by the lake mud, but it is equally possible that one was never built. Although crannogs by definition were once required to have palisades (Lynn, 1983), more recent work has shown that many crannogs did not have them or had partial rather than encircling palisades (O'Sullivan, 1998; Fredengren, 2002). The purpose of the two isolated wooden posts to the north of the crannog remains unclear. One possibility is that they are remains of an outer palisade (see O'Sullivan and Downey 2005: Fig 2), but seems odd that the remains of only two posts would survive both in close proximity and to a significant length above the lakebed with no such remains evident elsewhere.

Similarly, there is no definitive evidence for a causeway linking the lakeshore and the crannog. In this case, the area concerned was choked with weeds and vegetation which hindered both acoustic survey and diver observations. Nevertheless, SBES data indicate that water depth on the inside of the crannog rises gradually from c. $1.8 \mathrm{~m}$ to $1.2 \mathrm{~m}$ with the shallowest point directly between the crannog and the lakeshore, and thus hinting at a possible route for a causeway, if one was present (Figure 10).

No samples were taken for dating, but based on the size and general shape of the crannog (see Fredengren, 2002: Fig 20) there is a strong possibility that it dates to the (early) Medieval period. If so, then it could be associated with the two raths (circular earthwork enclosures) situated on high ground 600m west (FER246:044: NI SMR, 2016) and 330m east (FER246:0045: NI SMR, 2016) of the crannog (Figure 9). Neither are radiometrically dated or excavated, but along with the crannog, raths are regarded as the characteristic sites of the Irish early Medieval, and thus the Moorlough crannog could have provided a location for seasonal occupation or specialist activities for the inhabitants of these raths.

\section{Discussion}

In each of the inland waterways discussed here, useful archaeological data was obtained by remote sensing survey using a low-cost integrated SSS/SBES system. In all instances, this setup was used to detect relatively small and low lying anomalies and, for Coney Island and Moorlough Lake, these were subsequently ground-truthed as features of genuine archaeological interest, specifically a sunken barge, two logboats and wooden posts or timbers possibly associated with a crannog. The Moorlough data was also useful in delineating the full extent of the crannog mound, showing it to be much larger than appears above water. For Dunnalong, though ground-truthing has yet to be undertaken, the positioning of the main debris scatter coupled with historic accounts of the former settlement and/or quay structure suggest that some of the material may be of archaeological interest. For all surveys, though the primary role of the acquired bathymetry was to guide survey, in practice it provided added value in giving a rationale for the positioning of the fort and ferry at Dunnalong and suggesting possible former causeway routes for Coney Island and the Moorlough crannog.

Moreover, for all the case studies, the surveys conducted were the first to be done in 
these particular locations. All constitute areas which traditionally might be regarded as difficult to survey or archaeologically unpromising as they are shallow, uncharted, and in the case of Moorlough, have no formal boat access either by slip or waterway. This has been overcome by use of the integrated SBES/SSS setup on a small shallowdraft boat and demonstrated that such environments can be subject to effective archaeological survey. Elsewhere, similar systems have been employed, for example in Hungary, where they have been used for pre-dive prospection to great effect in the Drava River (Toth, 2006; Toth, 2009) and Lough Corrib (Republic of Ireland) where recent discoveries of multiple logboats were made off the back of a mapping project to make hydrographic charts for anglers (Brady, 2014a; 2014b; Northage, 2016). These recent projects supplement previous demonstrations using more conventional setups (e.g. Duck and McManus, 1987; Sonnenburg and Boyce, 2008).

While results here are encouraging and demonstrate the usefulness of the low-cost system, there are, however, some performance issues to be considered. One concerns the image quality of the SSS, which itself is partly controlled by its resolving power. Range to target and beam angle are particularly important for transverse (also referred to as along-track) resolution: the ability of the system to distinguish between two objects parallel to the line of travel and the primary determinant of image quality (Key, 2000; Quinn et al., 2005). Small beam angles create narrower beams and hence offer greater resolving power. In general, narrow beams are produced by longer transceiver arrays and higher frequencies (Key, 2000; Edgetech, 2005). Given that beam angle is dependent on transceiver array length, the fact that the LSS-1 has a short transceiver $(17.3 \mathrm{~cm})$ suggests it has a wide beam angle and hence lower resolving power. Moreover, since beams naturally spread away from the transceiver, the effective transverse resolution is also controlled by the range to the target. Consequently, distant targets will not be imaged to the same resolution as nearby targets.

These factors appear to be borne out by our experience of surveying with this system. In general, image quality decreases with swath width such that optimal range for object detection is $<30 \mathrm{~m}$ and with the best imagery collected with the target within c. $15 \mathrm{~m}$ of the transceiver. This is illustrated in Figure 11 which shows wreckage and associated debris imaged during a survey of the Foyle Bridge area (River Foyle; see Figure 1 for location). Based on discussion with the harbourmaster, this wreckage probably represents the base of a former navigation beacon. Other man-made objects are also present immediately adjacent to the wreckage including at least two circular objects interpreted as car tyres and, to the west, a rectangular patch of smaller upstanding objects, possibly representing pile bases. In this case, the nature of this survey (confirmation of an anomaly originally reported during a search and recovery operation for a missing person: see Westley, 2012) meant that the same piece of wreckage was imaged on multiple passes at a distance of 5-10 m from the transceivers, but at different ranges and frequencies. Thus Figure $11 \mathrm{~A}$ and $11 \mathrm{~B}$ show the difference between $800 \mathrm{kHz}$ and $455 \mathrm{khz}$ settings at $30 \mathrm{~m}$ range, while $11 \mathrm{~B}$ and $11 \mathrm{C}$ compare $455 \mathrm{kHz}$ but at ranges of $30 \mathrm{~m}$ and $60 \mathrm{~m}$. From these it is clear that the LSS-1 is capable of detecting the wreckage as a man-made anomaly at close ranges $(<15 \mathrm{~m})$ and both 
frequencies. This is true even with the LSS-1's lower resolution $(455 \mathrm{kHz})$ mode (Figure 11B). However, the tyres and pilings immediately adjacent to the wreckage are no longer discernible, though another tyre c. $20 \mathrm{~m}$ south of the wreckage is identifiable. Performance worsens as swath width increases. This is illustrated in Figure $11 \mathrm{C}$ which shows the same wreckage, again imaged at $455 \mathrm{kHz}$ but using a larger range $(60 \mathrm{~m})$. Even though the wreckage is located c. $10 \mathrm{~m}$ from the transceivers it shows up only as a faint anomaly with no discernible structure. Therefore, this shows that there are limitations to the imaging ability of the low-cost system, and that the choice of frequency and range are particularly important in its ability to detect small objects, such as archaeological assets often are.

In addition, the low-cost setup as used here has three disadvantages. Firstly, the inability to raise/lower the transceivers with changing water depth which, in our experience, makes the low-cost system less effective when water depth increases beyond c. $20 \mathrm{~m}$. Either the water column takes up most of the data, or if compensated for by increasing the range, resolution decreases and small anomalies become harder to see. Further, since acoustic shadows can play a major role in object identification (Bates et al., 2011), it can be important to maximize these by dropping the towfish to a minimum height above seabed. This is simply not possible with the current set up of hull-mounted transceivers. Secondly, a fixed mounting means that the transceivers are more sensitive to survey vessel motion compared to a towed setup in which the tow cable damps some of the motion. Consequently, when conditions are less than optimal, for instance with waves and strong currents, the resulting data often contain numerous distortions from heave and course corrections. Thirdly, noise in the data is also a factor, due to the proximity to the survey vessels' engines compared to a towed system. However, this tends to only affect one channel (that closest to the engines) and can be mitigated by surveying at sufficiently low speed $(<3-4 \mathrm{kts})$, increasing the distance between the transceiver and engine or almost completely eliminated by using an electric engine.

That said, all the above disadvantages are mitigated in shallow confined inland waterways. The limited swath width and depth range is compensated for by the generally small areal extent and depth of the target waterbodies. They also tend to be calmer than offshore environments, hence reducing distortions caused by survey vessel motion. This in turn means that less powerful engines (including quiet electric motors) are feasible which has the effect of reducing noise in the data even when the transducers are transom-mounted. Consequently, the setup described here is bestsuited for shallow, restricted inland waterways. Hull- or pole-mounting the small transceivers also reduces the potential for snagging or impacting the river/lakebed and allows tight manoeuvring, which is often necessary in these restricted waterways. The small size of the integrated topside unit is also an advantage, particularly when using the requisite small and shallow draft boats. In short, the combination of a small integrated SBES and SSS in an easily portable package allows the logistical challenges of surveying confined waterways described in the introduction to be easily overcome. 
This is not to say that conventional SSS and SBES systems are not effective in these environments. On the contrary, relatively portable survey-grade systems are available which can be pole-mounted and it would be desirable to have the improved accuracy, image quality and range which comes with such a system. Unfortunately, the reality is that as equipment improves, so too does the price and consequently, their use may be unaffordable to projects or organizations which are on a tight budget. This may be particularly true of inland waterways, given their comparative lack of attention compared to offshore and marine environments. In these situations, as demonstrated here, and provided that its limitations are understood and accounted for, the low cost system can be an adequate substitute capable of acquiring data that are sufficient for archaeological purposes.

\section{Conclusion}

In the case studies presented here, a series of shallow confined inland waterways have been subject to effective archaeological survey using a low-cost integrated SSS/SBES system. This has allowed potential insights into the location of former structures and the identification of archaeological anomalies for follow up ground-truthing. In these cases, the low-cost system has proved a useful addition to the archaeological toolkit. Although these system should not be seen as a direct replacement for survey-grade systems owing to limitations in their useful depth and range of operation and reduced image quality, they do perform well in shallow, confined waterways where their disadvantages are minimized. Under such conditions, image quality and their object detection ability is sufficient for archaeological purposes and they can be considered to be an acceptable substitute for more expensive survey-grade systems. The traditional difficulty of surveying low visibility, shallow, restricted and inaccessible waterways means that they may hold a great deal of unrecorded or poorly-documented material. Geophysical approaches, such as discussed here, are one means by which to open up the possibility of effective survey of these submerged heritage assets and offer opportunities for improved mitigation in development contexts; record enhancement and new underwater archaeological research.

\section{Acknowledgements}

All survey work presented here was supported by the Northern Ireland Environment Agency; we thank our colleagues there, notably Rhonda Robinson, Paul Logue and Claire Foley. All historic maps were supplied by Land and Property Services under the Northern Ireland Mapping Agreement. Survey and ground-truthing would not have been possible without assistance from colleagues at Ulster University, in particular, Colin Breen, Wes Forsythe, Sandra Henry and Chris McGonigle. Special thanks to Rory Quinn for his insightful comments on the manuscript and knowledge of all things sidescan-related and Nigel Macauley for applying his workshop savvy in the construction of the various deployment rigs. 


\section{References}

Addyman P. 1965. Coney Island, Lough Neagh: Prehistoric settlement, Anglo-Norman castle and Elizabethan native fortress: An interim report on excavations in 1962 to 1964. Ulster Journal of Archaeology 28: 78-101.

Bates CR, Lawrence M, Dean M, Robertson P. 2011. Geophysical methods for wrecksite monitoring: the Rapid Archaeological Site Surveying and Evaluation (RASSE) programme. International Journal of Nautical Archaeology 40(2): 404-416.

Bates CR, Fenning P. 2013. An adaptable survey A-platform for shallow water. Hydro International. (http://www.hydro-international.com/content/article/an-adaptablesurvey-platform-for-shallow-water). Last accessed May 2016.

Bates MR, Nayling N, Bates CR, Dawson S, Huws D, Wickham-Jones C. 2013. A multidisciplinary approach to the archaeological investigation of a bedrock-dominated shallow-marine landscape: an example from the Bay of Firth, Orkney, UK. International Journal of Maritime Archaeology 42: 24-43.

Bermingham N, Moore C, O'Keeffe J, Gormley M. 2013. Drumclay: a most surprising crannog. Archaeology Ireland 27(2): 37-40.

Boland D. 1994. Underwater Archaeology in Ireland. Archaeology Ireland 8(3): 13-14.

Boland D, O'Sullivan. A. 1997. An early medieval wooden bridge at Clonmacnoise. In The Quaternary of the Irish Midlands, Mitchell F, Delaney C (eds), Field Guide 21. Irish Association for Quaternary Studies: Dublin; 14-21.

Bourke C. 1998. Fine Metalwork from the River Blackwater. Archaeology Ireland 12(3): 30-31.

Bourke L. 2001. Crossing the Rubicon: Bronze Age Metalwork from Irish Rivers. National University of Ireland, Galway: Galway.

Bradley J. 1991. Excavations at Moynagh Lough, Co. Meath. Journal of the Royal Society of Antiquaries of Ireland 111: 5-26

Brady N. 2000. John's Bridge, River Nore, Kilkenny (2000:0538). Excavations.ie online database of Irish Excavation reports.

(http://www.excavations.ie/report/2000/Kilkenny/0005363/). Last accessed May 2016

Brady N. 2001. John's Bridge, River Nore, Kilkenny (2001:704). Excavations.ie online database of Irish Excavation reports.

(http://www.excavations.ie/report/2001/Kilkenny/0006642/L. Last accessed May 2016 
Brady K. 2014a. The logboats in the lake. Current Archaeology 292: 10-15.

Brady K. 2014b. Secrets of the lake: the Lough Corrib logboats. Archaeology Ireland 28(4): 34-38.

Brown A. 1997. Alluvial Geoarchaeology. Floodplain Archaeology and Environmental Change. Cambridge University Press: Cambridge.

Cantelas F, Rodgers B. The Maple Leaf: a case study in cost-effective zero-visibility riverine archaeology. International Journal of Nautical Archaeology 23: 271-282.

Cassen S, Baltzer A, Lorin A, Fournier J, Sellier D. 2011. Submarine Neolithic Stone Rows near Carnac (Morbihan), France: preliminary results from acoustic and underwater survey. In Submerged Prehistory, Benjamin J, Bonsall C, Pickard C, Fischer A. (eds). Oxbow: Oxford; 99-110.

Coles J. 1984. The archaeology of wetlands. Edinburgh University Press: Edinburgh.

Coles J, Coles B. 1989. People of the wetlands. Bogs, bodies and lake-dwellers. Thames and Hudson: London.

Coles J, Lawson A. 1987. European wetlands in prehistory. Oxford University Press: Oxford.

Collins A. 1955. Excavations at Lough Faughan crannog, Co. Down, 1950-51. Ulster Journal of Archaeology 22: 92-101

Condit T, O'Sullivan A. 1999. Landscapes of movement and control: interpreting prehistoric hillforts and fording-places on the River Shannon. Discovery Programme Reports 5: 25-39.

Conneller C, Milner N, Taylor B, Taylor M. 2012. Substantial settlement in the European Early Mesolithic: new research at Star Carr. Antiquity 86: 1004-1020.

Croes D, Fagan J, Zehendner M. 2009. Sunken Village, Sauvie Island, Oregon, USA: A Report on the 2006-2007 Investigations of National Historic Landmark Wet Site 35MU4. Journal of Wetland Archaeology 9: 1-215.

Day A, McWilliams P. 1990. Ordnance Survey Memoirs of Ireland. Parishes of County Armagh 1835-8. Institute of Irish Studies: Belfast.

Delany R. 1988. A Celebration of 250 years of Ireland's Inland Waterways. Appletree Press: Belfast.

Duck R, McManus K. 1987. Sidescan sonar applications in limnoarchaeology. 
Geoarchaeology: An International Journal 2: 223-230.

Edgetech. 2005. Application note: Sidescan sonar beamwidth.

(http://www.edgetech.com/pdfs/ut/app note beamwidth.pdf). last accessed May 2015.

Farrell R, Buckley V. 1984. Preliminary examination of the potential of offshore and underwater sites in Loughs Ennell and Analla, Co. Westmeath, Ireland. International Journal of Nautical Archaeology 13: 281-285.

Farrell R. 1989. The Crannog Archaeological Project (CAP), Republic of Ireland II: Lough Lene - offshore island survey. International Journal of Nautical Archaeology 18: 221228.

Farrell R, Kelly E, Gowan M. 1989. The Crannog Archaeological Project (CAP), Republic of Ireland: a pre-preliminary report. International Journal of Nautical Archaeology 18: 123-136.

Firth A. 2011. Marine Geophysics: integrated approaches to sensing the seabed. In Remote Sensing for Archaeological Heritage Management. Proceedings of the $11^{\text {th }}$ EAC Heritage Management Symposium, Cowley D (ed). EAC Occasional Paper 5. EAC: Brussels; 129-142.

Firth A, Callan N, Scott G, Gane T, Arnott S. 2012. London Gateway. Maritime Archaeology in the Thames Estuary. Wessex Archaeology Report No. 30. Wessex Archaeology: Salisbury.

Firth A. 2014. Heritage Assets in Inland Waters. Report Prepared for English Heritage. Fjordr Ltd: Salisbury.

Foley C, William B. 2006. The Crannogs of County Fermanagh. In The Modern Traveller to Our Past: Festschrift in Honour of Ann Hamlin, Meek M (ed). Colourbooks: Dublin; 53-64.

Fredengren C. 2002. Crannogs. Wordwell: Bray

Fredengren C, Kilfeather A, Stuijts I. 2010. Lough Kinale: studies of an Irish lake. Discovery Program Monograph 8. Wordwell: Dublin.

Fry M. 2000. Coiti: Logboats from Northern Ireland. Greystone Press: Antrim.

Gaffney V, Thomson K, Fitch S (eds). 2007. Mapping Doggerland: The Mesolithic Landscapes of the Southern North Sea. Archaeopress: Oxford.

Hare R. 2008. Small boat surveys in shallow water. In Marine Habitat Mapping 
Technology for Alaska, Reynolds J, Green H (eds) Alaska Sea Grant for North Pacific Research Board: Fairbanks; 71-89.

Hamel A. 2011 Wrecks at Sea: Marine ALSF Research in Context. Marine ALSF Science Monograph Series No. 6. Marine Aggregates Levy Sustainability Fund.

Hencken H. 1950. Lagore crannog: an Irish royal residence of the seventh to tenth century A.D. Proceedings of the Royal Irish Academy 53C: 1-248.

Henderson J. 1998. A survey of crannogs on the Lake of Menteith, Stirlingshire. Proceedings of the Society of Antiquaries of Scotland 128: 273-292.

Henry S, Westley K, Forsythe W. 2014. Fermanagh Crannog Identification Project. Report prepared for the Northern Ireland Environment Agency: Historic Environment Division. pp. 49.

Howard A, Challis K, Holden J, Kincey M, Passmore D. 2008. The impact of climate change on archaeological resources in Britain: a catchment scale assessment. Climatic Change 91: 405-422.

Howard A, Knight D, Coulthard T, Hudson-Edwards K, Kossoff D, Malone S. (in press). Assessing riverine threats to heritage assets posed by future climate change through a geomorphological approach and predictive modelling in the Derwent Valley Mills WHS, UK. Journal of Cultural Heritage

Hunter R. 2011. Strabane Barony during the Ulster Plantation 1607-1641. Ulster Historical Foundation: Belfast.

Kaeser A, Litts T, Tracy T. 2013. Using low-cost side-scan sonar for benthic mapping throughout the lower Flint River, Georgia, USA. River Research and Applications 29: 634-644.

Keane M. 1995. Lough More, Co. Mayo: the crannog. Irish Archaeological Wetland Unit Transactions 4: 167-182

Kelly E. 1993. Investigation of ancient fords on the River Suck. Inland Waterways 20: 45.

Key W. 2000. Side scan sonar technology. OCEANS 2000 MTS/IEEE Conference and Exhibition 2: 1029-1033.

Lafferty B, Quinn R, Breen C. 2006. A side-scan sonar and high-resolution Chirp subbottom profile study of the natural and anthropogenic sedimentary record of Lower Lough Erne, northwestern Ireland. Journal of Archaeological Science 33(6): 756-766. 
Lavelle D. 1992. The Lough Carra causeway, Ireland. NewsWARP 11: 13-15.

Lanting J, Brindley A. 1996. Irish Logboats and Their European Context. Journal of Irish Archaeology 7: 85-95.

Logue P, McHugh R. 2013. The 2012 Excavation. In: The Lost Settlement of Dunnalong. Guildhall Press: Derry; 51-60.

Lübke H, Schmölckem U, Tauber F. 2011. Mesolithic hunter-fishers in a changing world: a case study of submerged sites on the Jäckelberg, Wismar Bay, northeastern Germany. In Submerged Prehistory, Benjamin J, Bonsall C, Pickard C, Fischer A. (eds). Oxbow: Oxford; 21-37.

Lynn C. 1983. Some 'early' ring-forts and crannogs. Journal of Irish Archaeology 1: 4758.

Malim T, Morgan D, Panter I. 2015. Suspended preservation: Particular preservation conditions within the Must Farm - Flag Fen Bronze Age landscape. Quaternary International 368: 19-30.

McCutcheon W. 1980. The Industrial Archaeology of Northern Ireland. HMSO: Belfast. McHugh R. 2013. The geophysical survey of Dunnalong fort. In: The Lost Settlement of Dunnalong. Guildhall Press: Derry; 46-50.

McKenna J, Quinn R, Donnelly D, Cooper JAG. 2008. Accurate Mental Maps as an Aspect of Local Ecological Knowledge (LEK): a Case Study from Lough Neagh, Northern Ireland. Ecology and Society 13(1): 1-23.

McNeary R, Bourke L. 2009. Freshwater archaeology in Northern Ireland. Archaeology Ireland 23(2): 38-39.

McNeary R. 2010. Freshwater Archaeology in Northern Ireland: summary strategy document for rivers. Report prepared for the Northern Ireland Environment Agency: Built Heritage Division. 146pp.

McNeary R. 2011. Riverine Archaeology in Northern Ireland: an evaluation. International Journal of Nautical Archaeology 40(1): 162-170.

McNeary R. 2012a. Underwater Investigations at Dunnalong Fort 2012. Unpublished report prepared for the Northern Ireland Environment Agency, Dept. of the Environment. 32pp.

McNeary R. 2012b. Underwater Investigations at Rindoon 2012. Unpublished report prepared for St. John's Parish Heritage Group and the Royal Irish Academy. 60pp. 
McNeary R. 2013. Maritime Archaeology and the river. In: The Lost Settlement of Dunnalong. Guildhall Press: Derry; 36-41.

McNeary R, Campbell L, O'Keeffe J, Robinson R. 2013. Beyond the gloom. Archaeology Ireland 27(1): 37-39.

Menotti F. 2012. Wetland archaeology and beyond: theory and practice. Oxford University Press: Oxford.

Menotti F, O'Sullivan A. (eds). 2013. The Oxford Handbook of Wetland Archaeology. Oxford University Press: Oxford.

Moore F. 1996. Ireland's Oldest Bridge: At Clonmacnoise. Archaeology Ireland 10(4): 24-27.

Neill K. 2014. Early Christian Secular Monuments. In An Archaeological Survey of County Fermanagh: Volume 1, Part 2: Early Christian and Medieval Periods, Foley C, McHugh R (eds). Northern Ireland Environment Agency: Belfast; 305-327.

NI SMR. 2016. Northern Ireland Sites and Monuments Record. (http://apps.ehsni.gov.uk/ambit/ ). Last accessed May 2016.

Northage T. 2016. Fishing and cruising charts for Lough Corrib and lakes in the west of Ireland. (http://www.anglingcharts.com/). Last accessed May 2016.

O’Connor N. 1989. Underwater Archaeology. Archaeology Ireland 3(1): 26-29.

O'Sullivan A. 1998. The Archaeology of Lake Settlement in Ireland. Discovery Programme Monograph 4. Royal Irish Academy. Dublin.

O'Sullivan A. 2007. Exploring past people's interactions with wetland environments in Ireland. Proceedings of the Royal Irish Academy 107C: 147-203

O'Sullivan A, Sands R, Kelly E. 2007. Coolure Demesne crannog, Lough Derravaragh: an introduction to its archaeology and landscapes. Wordwell: Bray.

O’Sullivan M, Downey L. 2005. Crannogs. Archaeology Ireland 19(4): 34-36.

Palomo A, Piqué R, Terradas X, Bosch A, Buxó R, Chinchilla J, Saña M, Tarrús J. 2014. Prehistoric cccupation of Banyoles lakeshore: results of recent excavations at La Draga site, Girona, Spain. Journal of Wetland Archaeology 14: 58-73.

Papatheodorou G, Geraga M, Ferentinos G. 2005. The Navarino naval battle site, Greece - an integrated remote-sensing survey and rational management approach. 
International Journal of Nautical Archaeology 34(1): 95-109.

Parker R, Ruffell A, Hughes D, Pringle J. 2010. Geophysics and the search of freshwater bodies: A review. Science and Justice 50: 141-149.

Plets R, Dix J, Adams J, Bull J, Henstock T, Gutowski M, Best A. 2009. The use of a highresolution 3D Chirp sub-bottom profiler for the reconstruction of the shallow water archaeological site of the Grace Dieu (1439), River Hamble, UK. Journal of Archaeological Science 36(2): 408-418

Plets R, Quinn R, Forsythe W, Westley K, Bell T, Benetti S, McGrath F, Robinson R. 2011. Using Multibeam Echo-Sounder Data to Identify Shipwreck Sites: archaeological assessment of the Joint Irish Bathymetric Survey data. International Journal of Nautical Archaeology 40(1): 87-98.

Plets R. 2013. Underwater survey and acoustic detection and characterization of archaeological materials. In The Oxford Handbook of Wetland Archaeology, Menotti F, O'Sullivan A. (eds). Oxford University Press: Oxford; 433-449.

Ryan M. 1980. An early Mesolithic site in the Irish midlands. Antiquity 80: 46-47.

Quinn R, Breen C, Forsythe W, Barton K, Rooney S, O'Hara D. 2002. Integrated geophysical surveys of the French frigate La-Surveillante (1797), Bantry Bay, Co. Cork, Ireland. Journal of Archaeological Science 29(4): 413-422.

Quinn R, Dean M, Lawrence M, Liscoe S, Boland D. 2005. Backscatter responses and resolution considerations in archaeological side-scan sonar surveys: a control experiment. Journal of Archaeological Science 32(8): 1252-1264.

Quinn R. 2007. The assimilation of marine geophysical data into the maritime sites and monuments record, Northern Ireland. Historical Archaeology 41(3): 9-24.

Quinn R. 2011. Acoustic Remote Sensing in Maritime Archaeology. In The Oxford Handbook of Maritime Archaeology. Catsambis A, Ford B, Hamilton DL (eds). Oxford University Press: Oxford; 68-89.

Raftery B. 1982. Two recently discovered shields from the Shannon Basin. Journal of the Royal Society of Antiquaries of Ireland 112: 5-17.

Rönnby J. 1990. New research at Bulverket Lake Building, Gotland, Sweden. International Journal of Nautical Archaeology 19(3): 233-237.

Roulston W. 2010. Three centuries of life in a Tyrone parish: a history of Donagheady from 1600 to 1900. Strabane Historical Society: Letterkenny. 
Roulston W. 2013. Fort of the ships: Dunnalong through the ages. In: The Lost Settlement of Dunnalong. Guildhall Press: Derry; 10-19.

Stickel E, Garrison E. 1988. New applications of remote sensing: geophysical prospection for underwater archaeological sites in Switzerland. In Wet Site Archaeology, Purdy B (ed.). Telford Press: New Jersey; 69-87.

Sonnenburg E, Boyce J. 2008. Data-fused digital bathymetry and side-scan sonar as a base for archaeological inventory of submerged landscapes in the Rideau Canal, Ontario, Canada. Geoarchaeology: An International Journal 23(5): 654-674.

Tóth A. 2006. River archaeology-a new field of research. Archeometriai Mühely 1: 6166.

Tóth A. 2009. La Drava (Hongrie). Un fleuve inconnu. Dossiers d'Archaeologie 331: 4649.

UK Lakes Portal. 2016. Lough Neagh.

(https://eip.ceh.ac.uk/apps/lakes/detail.html\#wbid=50001). Last accessed April 2016.

Wakeman W. 1870-1. Remarks upon three hitherto unnoticed crannogs in Drumgay Lake, near Enniskillen. Journal of the Royal Society of Antiquaries of Ireland 11: 232-

235.

Wakeman W. 1872. Observations on the principal crannogs of Fermanagh. Journal of the Royal Society of Antiquaries of Ireland ( $4^{\text {th }}$ series) 2: 216.

Wallace J. 1917. A Find of Oak Dug-Outs. Journal of the Royal Society of Antiquaries of Ireland 7(1): 85-86.

Westley K. 2012. 'Foyle anomaly' survey report. Unpublished report prepared for the Northern Ireland Environment Agency, Dept. of the Environment. 22pp.

Westley K, Plets R, Quinn R. 2014. Holocene palaeo-geographic reconstructions of the Ramore Head area, Northern Ireland, using geophysical and geotechnical data: palaeolandscape mapping and archaeological implications, Geoarchaeology: An International Journal 29: 411-430.

Wood-Martin W. 1886. The lake dwellings of Ireland or ancient lacustrine habitations or Erin commonly called crannogs. Dublin.

Woodman P. 2015. Ireland's First Settlers: Time and the Mesolithic. Oxbow: Oxford. 
Tables

Table 1. Summary table showing survey parameters for each of the case studies discussed in this paper

\begin{tabular}{|l|l|l|l|l|l|l|}
\hline & Date & $\begin{array}{l}\text { Line } \\
\text { Spacing } \\
(\mathbf{m})\end{array}$ & $\begin{array}{l}\text { Frequency } \\
(\mathbf{k H z})\end{array}$ & $\begin{array}{l}\text { Range } \\
(\mathbf{m})\end{array}$ & $\begin{array}{l}\text { Overall } \\
\text { trackline } \\
\text { length } \\
(\mathbf{k m})\end{array}$ & Aim \\
\hline Dunnalong 1 & $25 / 07 / 2012$ & $20 \mathrm{~m}$ & 455 & $25 \mathrm{~m}$ & $27.6 \mathrm{~km}$ & $\begin{array}{l}\text { Primary: bathymetry of the fort/settlement } \\
\text { environs } \\
\text { Secondary: anomaly detection }\end{array}$ \\
\hline Dunnalong 2 & $08 / 08 / 2012$ & $20 \mathrm{~m}$ & 455,800 & $20-25 \mathrm{~m}$ & $5.7 \mathrm{~km}$ & $\begin{array}{l}\text { Focus on the southern pool for anomaly } \\
\text { detection }\end{array}$ \\
\hline Coney Island 1 & $22 / 08 / 2013$ & $25 \mathrm{~m}$ & 455 & $30 \mathrm{~m}$ & $12.1 \mathrm{~km}$ & $\begin{array}{l}\text { Primary: bathymetry of Coney Island } \\
\text { environs } \\
\text { Secondary: anomaly detection }\end{array}$ \\
\hline Coney Island 2 & $29 / 08 / 2013$ & $10-20 \mathrm{~m}$ & 455,800 & $12-30 \mathrm{~m}$ & $8.9 \mathrm{~km}$ & Focus on high potential anomalies \\
\hline $\begin{array}{l}\text { Moorlough } \\
\text { Lake }\end{array}$ & $24 / 06 / 2014$ & $20-30 \mathrm{~m}$ & 455,800 & $18-25 \mathrm{~m}$ & $7.9 \mathrm{~km}$ & $\begin{array}{l}\text { Primary: identify potential crannog remains } \\
\text { Secondary: anomaly detection }\end{array}$ \\
\hline
\end{tabular}


Figure 1. Location of case study areas. Only Dunnalong, Coney Island and Moorlough Lake are presented as full case studies, with data from the Foyle Bridge used only in the discussion. Darker grey areas show the main rivers and lakes within Northern Ireland. Inset shows general location relative to the island of Ireland. Coordinates are in Irish National Grid. $54 \times 37 \mathrm{~mm}(300 \times 300$ DPI) 

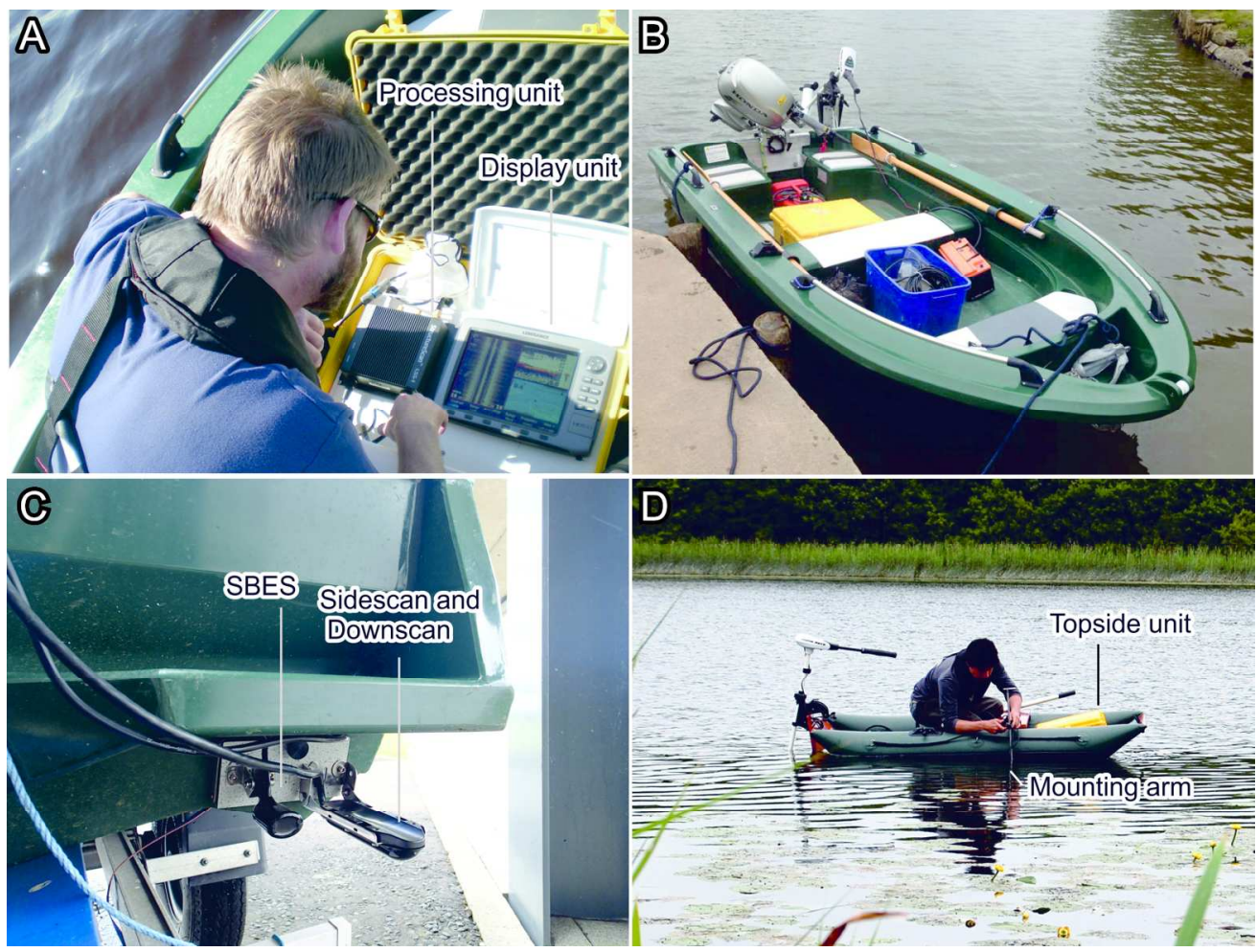

Figure 2. Setup of the LSS-1 system for use in inland waterways. A) Topside containing display and processing units. B) $3.5 \mathrm{~m}$ rigid hull boat used for most inland waterway surveys. C) Transceivers mounted on the stern of the $3.5 \mathrm{~m}$ rigid hull boat. D) Small inflatable used in inaccessible lakes. $159 \times 119 \mathrm{~mm}(300 \times 300 \mathrm{DPI})$ 

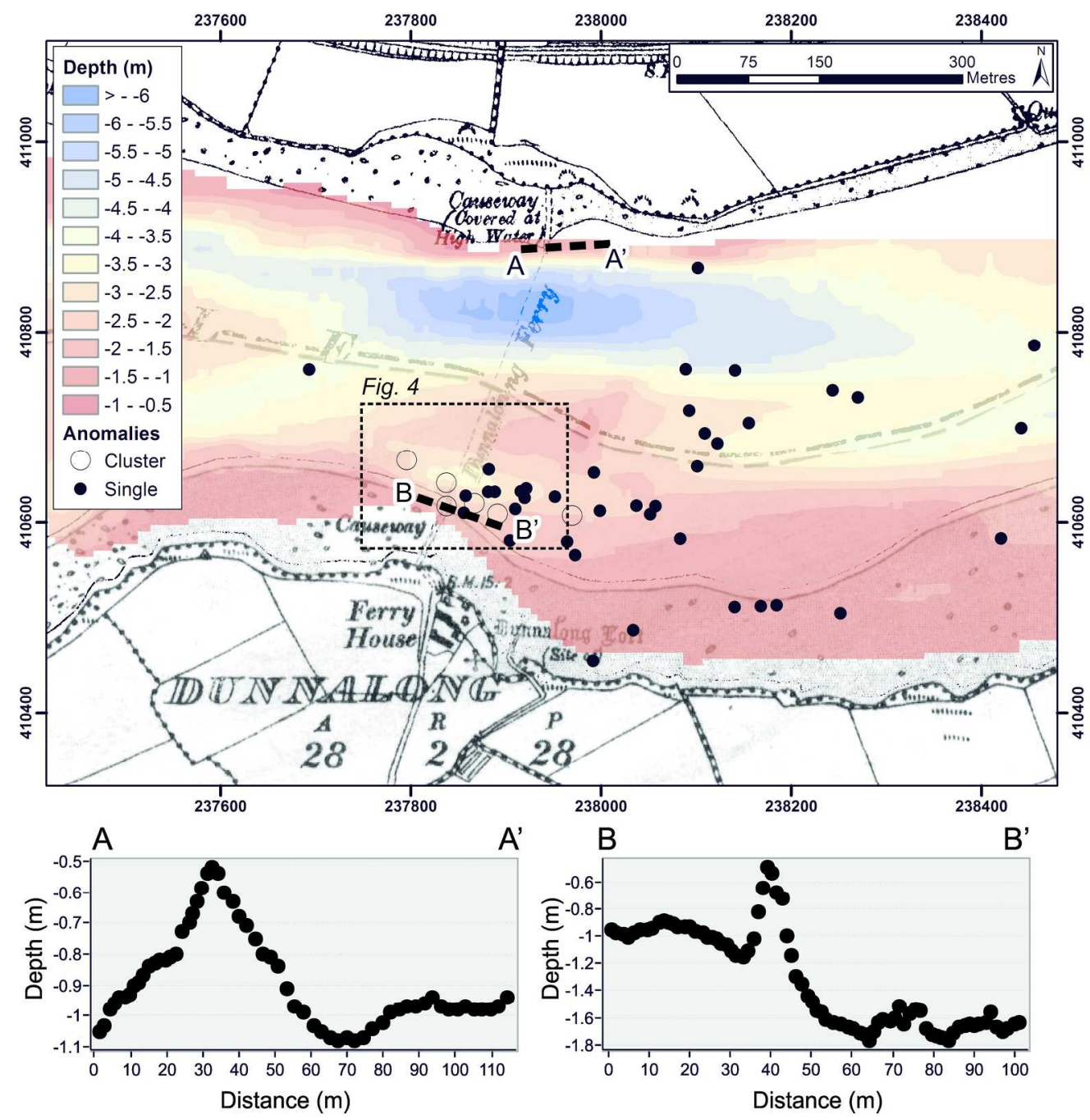

$A^{\prime} \quad B$

B'

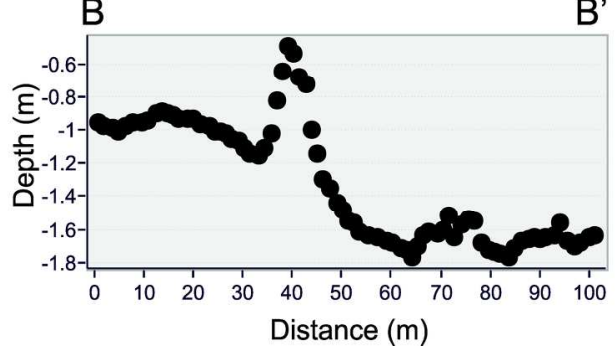

Figure 3. Bathymetric map generated from Phase 1 SBES data for the riverbed off Dunnalong superimposed onto a georeferenced Second Edition (1850-55) Ordnance Survey historic map. Note the location of the fort, ferry and causeways in relation to the deeper pools directly in front of them. Profiles A-A' and B-B' are from individual SBES lines which cross the submerged tips of the causeways and accordingly show a distinct 0.5$0.6 \mathrm{~m}$ high peak. Also shown are individual anomalies or anomaly clusters identified from the SSS from both Phases 1 and 2. $203 \times 209 \mathrm{~mm}(300 \times 300$ DPI $)$ 


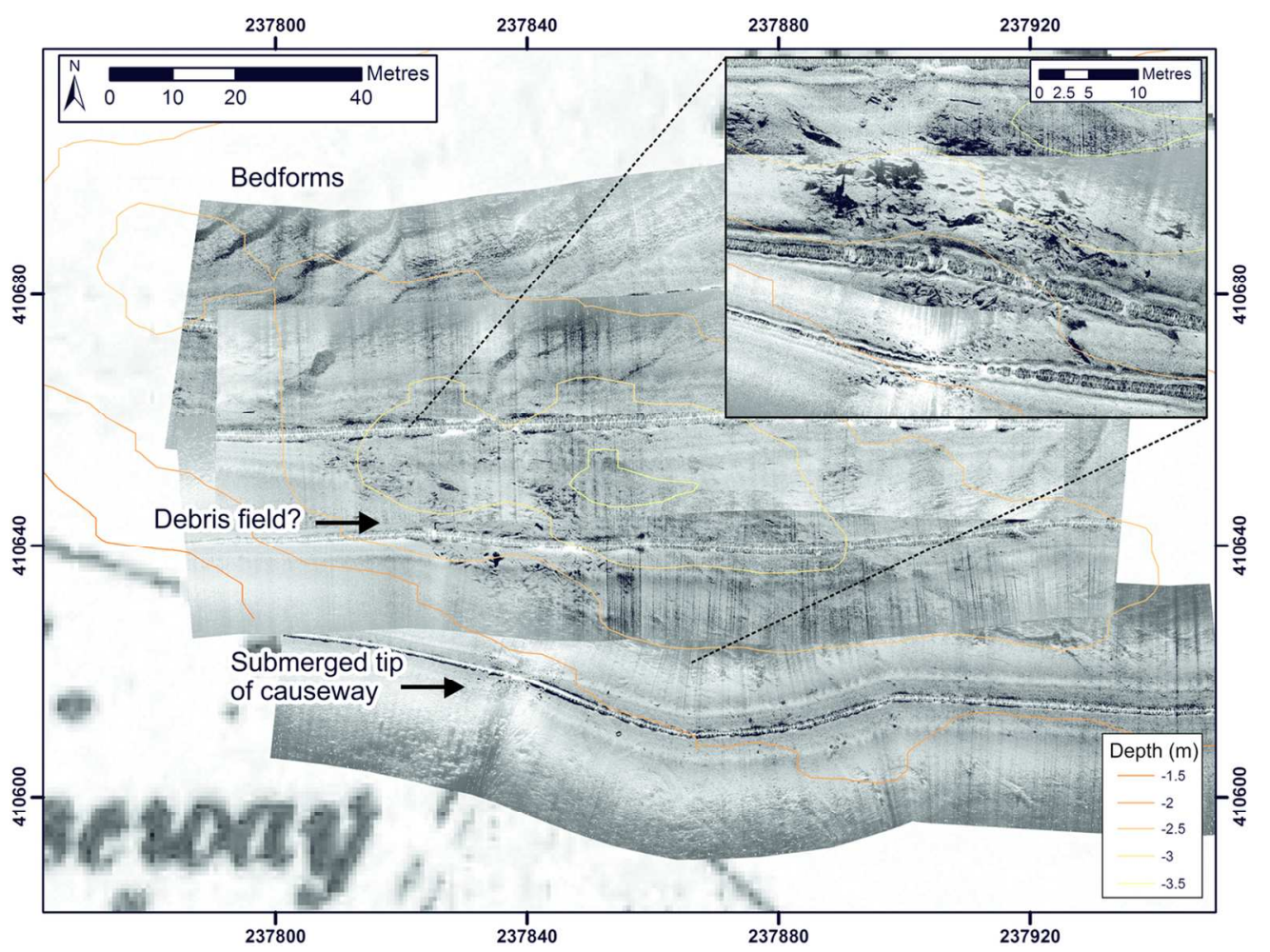

Figure 4. Sidescan sonar mosaic showing the submerged tip of causeway and possible debris field within the southern ferry pool. Main image shows data collected at $455 \mathrm{kHz}$ and $30 \mathrm{~m}$ range. Inset gives a close-up of the possible debris field using data collected at $800 \mathrm{kHz}$ and $20 \mathrm{~m}$ range. Note how the concentration of debris contrasts with the otherwise scattered anomalies and bedforms in the south and north of the mosaic respectively.

$118 \times 88 \mathrm{~mm}(300 \times 300$ DPI $)$ 


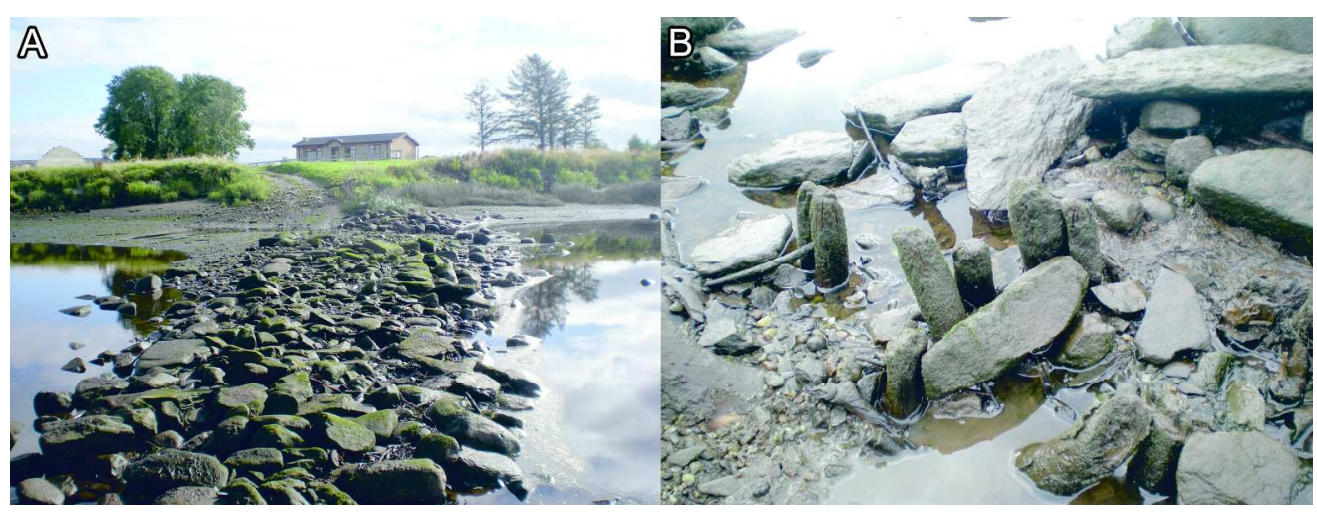

Figure 5. A) Southern causeway emerging at low water. B) Remains of wooden stakes protruding from boulder rubble along one edge of the south causeway. $219 \times 82 \mathrm{~mm}(300 \times 300 \mathrm{DPI})$ 
Figure 6. Aerial photograph showing location of Coney Island in the southwest corner of Lough Neagh and relevant placenames mentioned in the text. $110 \times 60 \mathrm{~mm}(300 \times 300 \mathrm{DPI})$ 
Fire 7. Second Edition (1858-60) Ordnance Survey historic map overlain with bathymetric map generated from SBES data for the area between Coney Island and the mainland. Also shown are the locations of SSS anomalies. Profiles $A-A^{\prime}, B-B^{\prime}$ and $C-C^{\prime}$ are taken from the interpolated bathymetric data and cross recorded $\left(A-A^{\prime}\right)$ and alternative $\left(B-B^{\prime}, C-C^{\prime}\right)$ routes for St. Patrick's Road. $193 \times 169 \mathrm{~mm}(300 \times 300 \mathrm{DPI})$ 

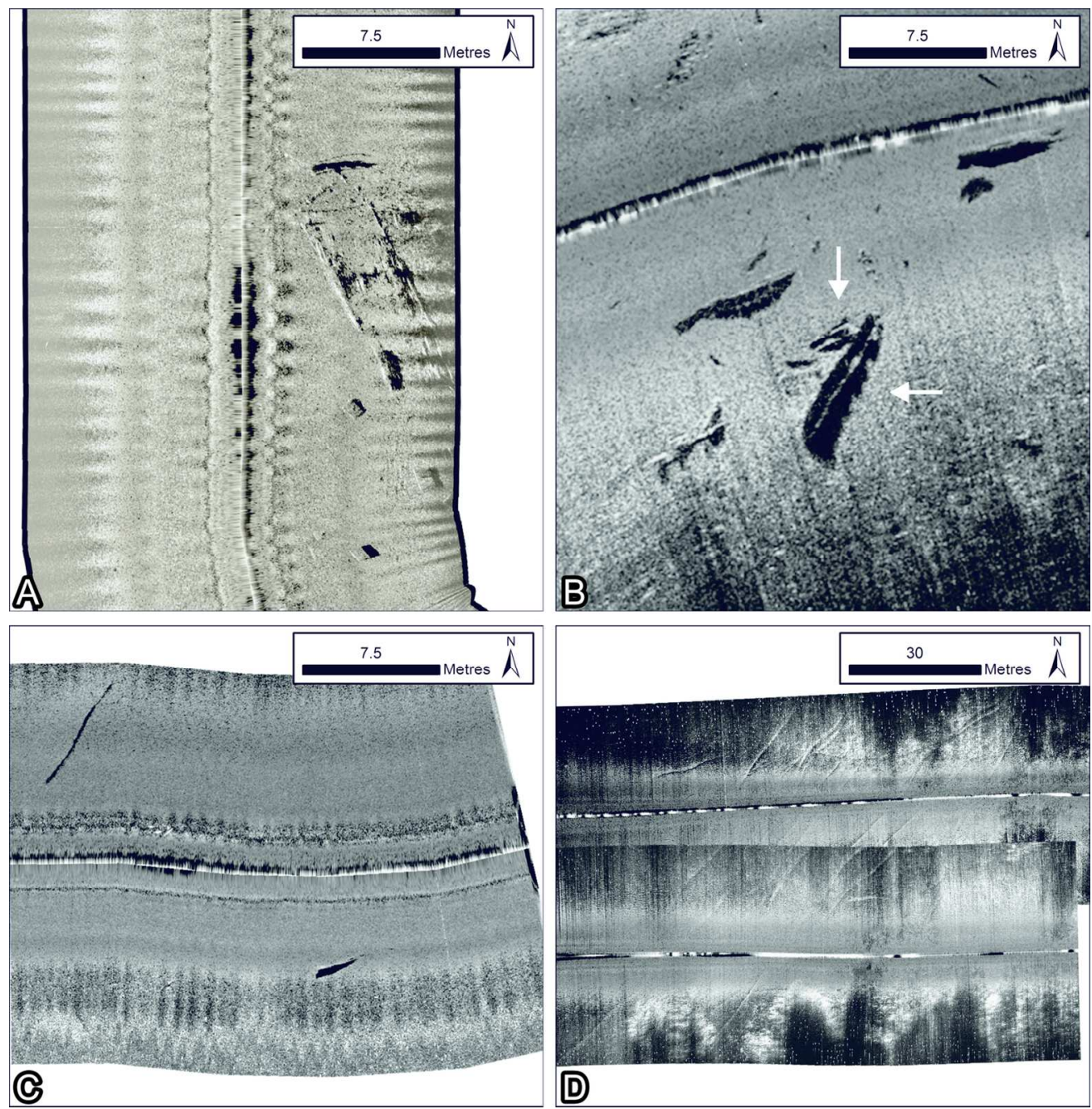

Figure 8. SSS data showing archaeological objects and anomalies in the vicinity of Coney Island A) Sunken canal barge and associated debris c. $250 \mathrm{~m}$ south of Coney Island in $2.5 \mathrm{~m}$ water depth. Data acquired at $800 \mathrm{kHz}$ and $20 \mathrm{~m}$ range. B) Two logboats (indicated by arrows) in $1.6 \mathrm{~m}$ water depth off the southeast shore of Coney Island. A number of other upstanding anomalies are also visible in the surrounding area which have not been subject to ground truthing. Data acquired at $455 \mathrm{kHz}$ and $25 \mathrm{~m}$ range. C) Two linear anomalies C. $300 \mathrm{~m}$ south of Coney Island in $2.4 \mathrm{~m}$ depth. These have not been ground-truthed. Data acquired at $800 \mathrm{kHz}$ and $12 \mathrm{~m}$ range. D) Sub-parallel scars on the lakebed c. $180 \mathrm{~m} \mathrm{SW}$ of Coney Island in $1-1.3 \mathrm{~m}$ water depth. These have not been ground-truthed but their general appearance is suggestive of anchor drag marks or possibly dredging activity. Data acquired at $455 \mathrm{kHz}$ and $30 \mathrm{~m}$ range $140 \times 143 \mathrm{~mm}(300 \times 300 \mathrm{DPI})$ 


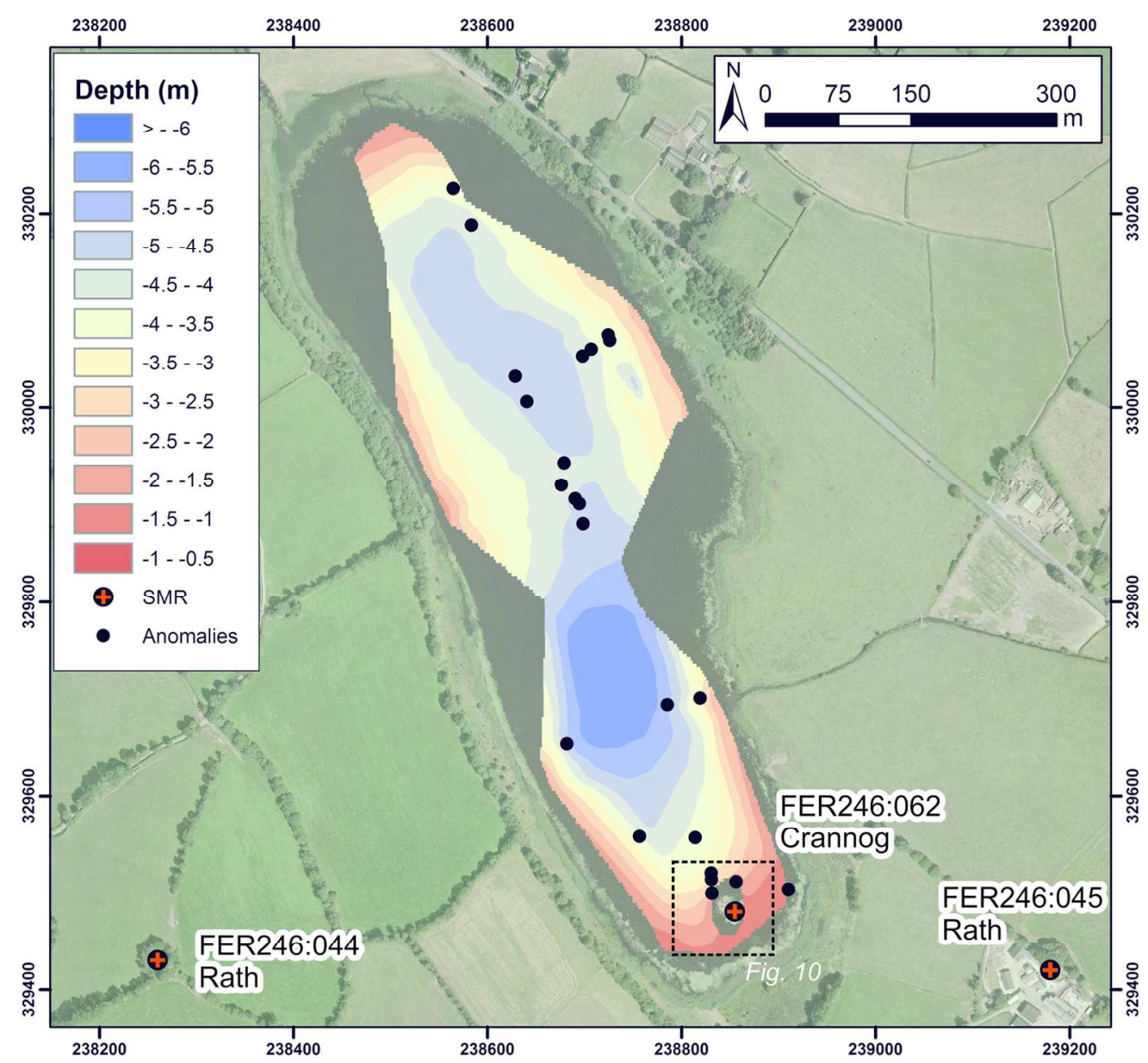

Figure 9. Aerial photo of the Moorlough Lake overlaid with bathymetric map interpolated from SBES bathymetry. Also shown are recorded archaeological sites in the vicinity of the Lough and anomalies detected by the SSS. $125 \times 116 \mathrm{~mm}(300 \times 300 \mathrm{DPI})$ 


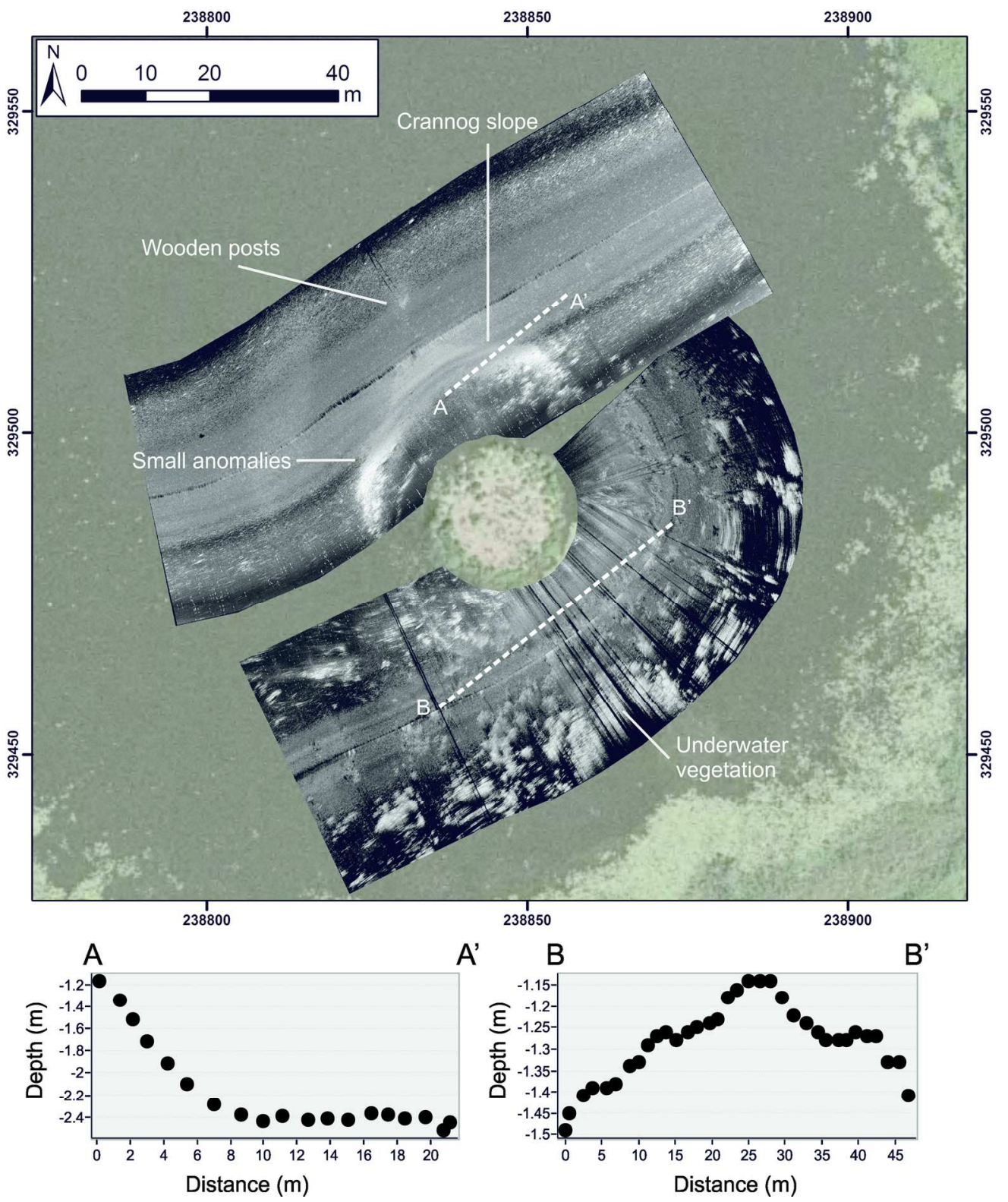

Figure 10. Aerial photo of the Moorlough Lake crannog overlaid with SSS mosaic. The semi-circular slope on the northwest side on the crannog is well-defined and shows how much larger the artificial island is compared to its above-water exposure. Also visible are the parallel acoustic shadows cast by two upstanding wooden posts and a number of small anomalies on the crannog slope, suggested by diver inspection to be reclining timbers or large stones. The southern and eastern sides of the crannog are heavily obscured by underwater vegetation, though the SSS data hint at the continuation of the submerged perimeter slope. Data collected at $455 \mathrm{kHz}$ and $25 \mathrm{~m}$ range. Profiles $A-A^{\prime}$ and $B-B^{\prime}$ are taken from individual SBES lines and respectively show the distinct slope of the crannog berm and shallowing, possibly indicative of a former causeway in its lakeshore side. $161 \times 193 \mathrm{~mm}(300 \times 300$ DPI $)$ 


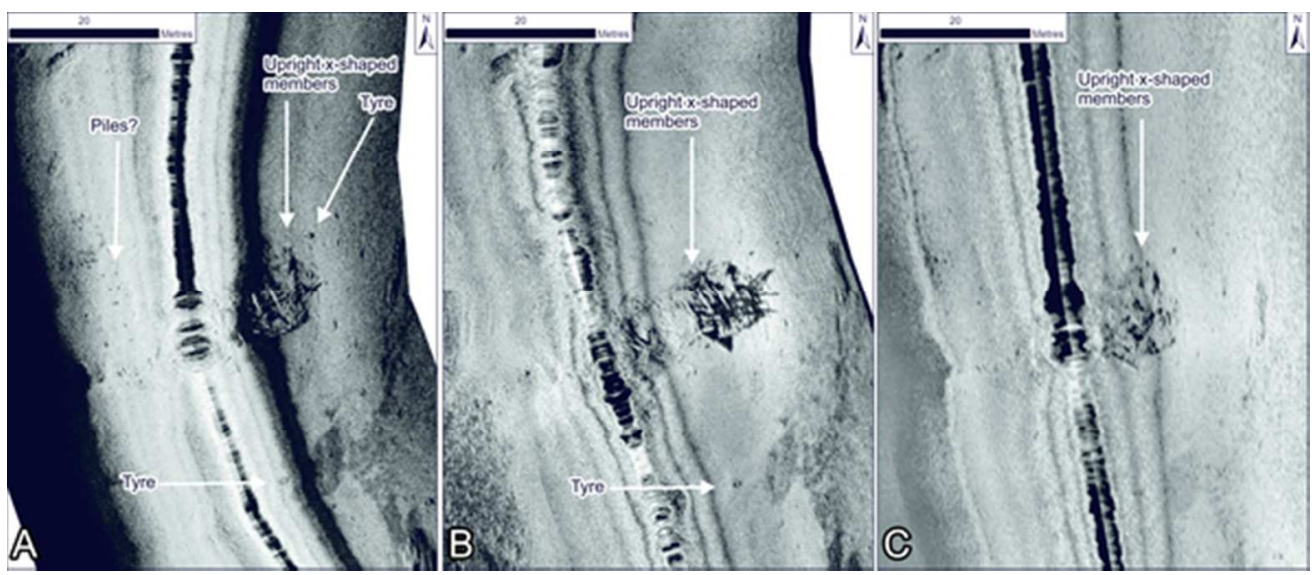

Figure 11. Comparison of Foyle Bridge wreckage imaged by the LSS-1 with varying ranges and frequencies. A) $800 \mathrm{kHz}, 30 \mathrm{~m}$ range. B) $455 \mathrm{kHz}, 30 \mathrm{~m}$ range. C) $455 \mathrm{kHz}, 60 \mathrm{~m}$ range. $50 \times 21 \mathrm{~mm}(300 \times 300 \mathrm{DPI})$ 